\title{
Connections between Spring Arctic Ozone and the Summer Circulation and Sea Surface Temperatures over the Western North Pacific
}

\author{
TAO WANG, WENSHOU TIAN, AND JiANKAi ZHANG \\ Key Laboratory for Semi-Arid Climate Change of the Ministry of Education, College of Atmospheric Sciences, Lanzhou \\ University, Lanzhou, China \\ FEI XIE \\ College of Global Change and Earth System Science, Beijing Normal University, Beijing, China \\ RUHUA ZHANG AND JINLONG HUANG \\ Key Laboratory for Semi-Arid Climate Change of the Ministry of Education, College of Atmospheric Sciences, Lanzhou \\ University, Lanzhou, China

\section{DINGZHU Hu} \\ Key Laboratory of Meteorological Disasters of China Ministry of Education/Joint International Research Laboratory of \\ Climate and Environment Change/Collaborative Innovation Center on Forecast and Evaluation of Meteorological Disasters, \\ Nanjing University of Information Science \& Technology, Nanjing, China
}

(Manuscript received 19 April 2019, in final form 11 December 2019)

\begin{abstract}
Using various observations, reanalysis datasets, and a general circulation model (CESM-WACCM4), the relationship between the Arctic total column ozone (TCO) and the tropospheric circulation and sea surface temperatures (SSTs) over the western North Pacific $\left(30^{\circ}-45^{\circ} \mathrm{N}, 130^{\circ} \mathrm{E}-170^{\circ} \mathrm{W}\right)$ was investigated. We find that anomalies in the circulation and SSTs over the western North Pacific in June are closely related to anomalies in the Arctic TCO in March; that is, when the Arctic TCO in March decreases, the anomalous tropospheric cyclone and negative SST anomalies (SSTAs) will occur over the western North Pacific in June. Further analysis indicates that the decreased Arctic TCO in March tends to result in positive Victoria mode (VM)-like SSTAs over the North Pacific in April, which persist and develop an anomalous cyclone over the eastern North Pacific in May via atmosphere-ocean coupling. This anomalous cyclone over the eastern North Pacific subsequently induces an anomalous cyclone over the western North Pacific in June via westward-propagating Rossby waves in the lower troposphere. Furthermore, the negative SSTAs over the western North Pacific are enhanced by the anomalous northerly wind related to the anomalous cyclone in June. The effects of increased Arctic TCO in March on the tropospheric circulation and SSTs are almost opposite to those of decreased Arctic TCO. These results are also supported by our numerical simulations. Moreover, $10 \%-20 \%$ of the anomalies in the tropospheric circulation and SSTs over the western North Pacific in June are affected by the anomalies in the Arctic TCO in March.
\end{abstract}

\section{Introduction}

Previous studies have reported that stratospheric circulation anomalies have an important effect on the tropospheric weather and climate (e.g., Baldwin and Dunkerton 2001; Graf and Walter 2005; Scaife et al. 2005; Cagnazzo and Manzini 2009; Ineson and Scaife

Corresponding author: Wenshou Tian, wstian@lzu.edu.cn
2009; Thompson et al. 2011; Reichler et al. 2012; Kidston et al. 2015; Sheng et al. 2015; Li et al. 2016; Zhang et al. 2016, 2018; Huang et al. 2017; Waugh et al. 2017; He et al. 2020). As a vital chemical component of the stratosphere, the loss and recovery of stratospheric ozone can affect, to a large degree, the stratospheric circulation through radiative processes (e.g., Ramaswamy et al. 1996; Labitzke and Naujokat 2000; $\mathrm{Hu}$ and Tung 2002; Tian et al. 2010; Hu et al. 2015). Thus, variations in the stratospheric ozone 
play an important role in the tropospheric climate change by influencing the stratospheric circulation (e.g., Hu and Tung 2003; Xie et al. 2016; Ivy et al. 2017; Garfinkel 2017).

The influence of Antarctic stratospheric ozone on the tropospheric climate change is a well-studied topic (e.g., Crook et al. 2008; Son et al. 2008; Waugh et al. 2009, 2015; Feldstein 2011; Hu et al. 2011; Kang et al. 2011; Gerber and Son 2014; Seviour et al. 2016; Xia et al. 2016) due to dramatic Antarctic stratospheric ozone loss (Farman et al. 1985; Ravishankara et al. 1994, 2009; Pawson and Naujokat 1999; Randel and Wu 1999, 2007; Solomon 1990, 1999). Antarctic ozone loss and the resulting ozone hole can induce a decrease in the Antarctic stratospheric temperature through radiative cooling (e.g., Randel and Wu 1999), which strengthens the Antarctic polar vortex. Furthermore, the strengthened westerlies associated with the Antarctic polar vortex extend downward from the stratosphere to surface and lead to the surface temperature changes over the Antarctic continent (Turner et al. 2005; Marshall et al. 2006). Many observations and simulations have demonstrated that the Antarctic ozone hole causes a poleward shift in the extratropical jet (Son et al. 2009, 2010), which is associated with a poleward shift in the subtropical dry and precipitation zones (Son et al. 2009; Polvani et al. 2011; Feldstein 2011; Kang et al. 2011), the extension of the Hadley cell (Min and Son 2013; Gerber and Son 2014; Waugh et al. 2015), and even changes in the ocean circulation (Russell et al. 2006; Bitz and Polvani 2012) in austral summer in the Southern Hemisphere (SH). In addition, the Antarctic stratospheric ozone also has effects on regional features of the $\mathrm{SH}$ climate, such as the Amundsen Sea low (England et al. 2016) and Antarctic precipitation (Lenaerts et al. 2018).

Although the multidecadal loss of Arctic ozone is much smaller than that of Antarctic ozone (WMO 2011), the interannual variability of Arctic total column ozone (TCO) is large due to the variability of stratospheric polar vortex (e.g., Solomon et al. 2014; Ivy et al. 2017). The years 1997 and 2011 exhibited the most severe ozone depletion ever recorded over the Arctic (Lefèvre et al. 1998; Coy et al. 1997; Manney et al. 2011). Thus, the influence of Arctic stratospheric ozone on the tropospheric climate has received increasing attention. However, there does not seem to be overwhelming consensus in the literature on the size and robustness of the effects of spring Arctic ozone at present, which may be related to the amplitudes of ozone change and model used in different studies. Cheung et al. (2014) used the stratospheric ozone anomalies to predict the tropospheric climate related to ozone changes and found that the tropospheric forecast errors in the medium-extended range are dominated by the spread of ensemble members. Using a general atmospheric circulation model, Karpechko et al. (2014) found that the tropospheric impacts largely come from the SSTs and the ozone anomalies seem to play a minor role. Based on model studies, Smith and Polvani (2014) found that for ozone anomaly amplitudes within the observed range of the last three decades, their model experiments do not show statistically significant impacts at the surface, while extreme Arctic ozone has a significant effect on tropospheric circulation, surface temperature, and precipitation. Subsequently, using a fully coupled stratosphere-resolving atmospheric model, Calvo et al. (2015) found that changes in the Arctic ozone induce large and robust anomalies in April-May tropospheric wind, temperature, and precipitation over large parts of the Northern Hemisphere (NH). Ivy et al. (2017) presented observational evidence for a connection between the Arctic stratospheric ozone in March and the tropospheric climate and found that the stratospheric ozone is a useful predictor of spring tropospheric climate in some regions of the NH. Xie et al. $(2016,2017 a, b)$ reported that the Arctic stratospheric ozone variations in March lead to SSTAs similar to the Victoria mode (VM) over the North Pacific in April and further influence El Niño-Southern Oscillation (ENSO) and tropical rainfall, which lag ozone changes by approximately 20 months. More recently, studies found that spring Arctic stratospheric ozone has effects on local precipitation in China (Xie et al. 2018) and in the northwestern United States (Ma et al. 2019). As mentioned above, many studies reported the effects of spring Arctic ozone on springtime climate in $\mathrm{NH}$; however, the effects of ozone on summertime climate in $\mathrm{NH}$ have not been clarified.

The VM is the second leading mode of SSTs over the North Pacific (Bond et al. 2003). The VM is closely related to marine ecosystem in North Pacific (e.g., Chenillat et al. 2012) and has important effects on climate, such as the South China Sea summer monsoon (Ding et al. 2018), precipitation (Ding et al. 2015a), tropical cyclones (Pu et al. 2019), and ENSO (e.g., Ding et al. 2015b; Xie et al. 2016), which further influences global climate (e.g., Kumar et al. 1999; Wang et al. 2000). Previous studies (e.g., Song et al. 2016) indicated that winter and spring VM anomalies can persist into summer through atmosphere-ocean coupling. Although many studies have found that changes in the Arctic stratospheric ozone influence the tropospheric climate in spring, it is unclear whether the effects of spring Arctic ozone on the tropospheric climate in the $\mathrm{NH}$ could persist into summer. If so, what are the associated mechanisms of the Arctic TCO variations in spring that 


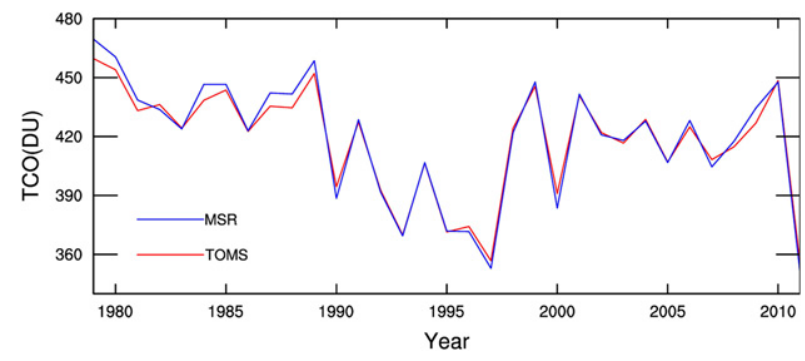

FIG. 1. Time series of Arctic $\left(60^{\circ}-90^{\circ} \mathrm{N}\right)$ TCO in March from the TOMS/SBUV (red line) and MSR (blue line) datasets.

impact summertime climate and to what extent do changes in the Arctic TCO affect the tropospheric summertime climate? Thus, in this paper, we analyze the impact of the Arctic TCO variations in March on the atmospheric circulation and SSTs over the North Pacific in early summer (June) and their associated mechanisms.

This paper is organized as follows. Section 2 describes methods and data. Section 3 analyzes the connections between Arctic TCO in March and the circulation and SSTs over the western North Pacific in June, as well as their underlying mechanisms. Section 4 gives the results of numerical simulations with high- and low-ozone conditions. Section 5 quantities the extent to which the variations of circulation and SSTs over the western North Pacific in June are explained by the March Arctic TCO changes. In section 6 , the conclusions and discussions are given.

\section{Methods and data}

\section{a. Observations and reanalysis datasets}

The TCO data are from the total ozone mapping spectrometer (TOMS)/solar backscatter ultraviolet (SBUV) dataset (Stolarski and Frith 2006) at a horizontal resolution of $5^{\circ} \times 10^{\circ}$ (latitude $\times$ longitude). The TCO data from the MSR (multisensor reanalysis) dataset (van der A et al. 2010, 2015), with a horizontal resolution of $0.5^{\circ} \times 0.5^{\circ}$ (latitude $\times$ longitude), are also used in this paper. Figure 1 shows the time series of the Arctic $\left(60^{\circ}-90^{\circ} \mathrm{N}\right)$ TCO in March in the TOMS/SBUV dataset and MSR dataset, and these two datasets show good consistency in describing the interannual variability of Arctic TCO. Note that in this paper, before calculating correlation coefficients between the Arctic TCO in March and other variables, the TCO value is multiplied by -1 so that a positive correlation corresponds to positive anomalies in Arctic TCO with decreasing years.

The SST data are obtained from the U.K. Met Office Hadley Centre for Climate Prediction and Research SST (HadSST) dataset and Extended Reconstructed Sea
Surface Temperature, version 4 (ERSSTv4). Geopotential height, temperature, and zonal and meridional wind are obtained from the European Centre for Medium-Range Weather Forecasts (ECMWF) interim reanalysis (ERAInterim) dataset and National Centers for Environmental Prediction Reanalysis 2 (NCEP2) data from the U.S. Department of Energy. Data used in this paper are monthly mean for the period 1979-2011.

\section{b. Model simulations}

The model used in this paper is the National Center for Atmospheric Research's Community Earth System Model (CESM), version 1.2.2. CESM is a fully coupled global climate model that incorporates an interactive atmosphere (CAM/WACCM) component, as well as ocean (POP2), land (CLM4), and sea ice (CICE). For the atmospheric component, we used the Whole Atmosphere Community Climate Model (WACCM), version 4 (Marsh et al. 2013). WACCM4 is a climate model that has detailed middle-atmosphere chemistry and a finite-volume dynamical core, and it extends from the surface to approximately $140 \mathrm{~km}$. For our study, we disabled the interactive chemistry in order to analyze the impact of stratospheric ozone changes in a specific month on the tropospheric circulations. WACCM4 has 66 vertical levels, with a vertical resolution of about $1 \mathrm{~km}$ in the tropical tropopause and lower-stratosphere layers. Our simulations used a horizontal resolution of $1.9^{\circ} \times 2.5^{\circ}$ (latitude $\times$ longitude) for the atmosphere and approximately the same for the ocean.

The original ozone data (zonal-mean ozone field) are from the CMIP5 ensemble-mean ozone output (19552005) and can be downloaded at https://svn-ccsm-inputdata. cgd.ucar.edu/trunk/inputdata/atm/waccm/ub/ghg_forcing 1955-2005_CMIP5_EnsMean.c140414.nc. We performed four transient experiments (R1-R4) with prescribed highand low-ozone scenarios to verify the influence of the stratospheric ozone on the tropospheric circulation and SSTs. Note that we used stratospheric ozone forcing with interannual variability in this study to obtain modeling results that are closer to the real atmosphere. The difference among these four runs is March ozone concentration in the Arctic region $\left(60^{\circ}-90^{\circ} \mathrm{N}\right)$ and the ozone concentrations are prescribed as shown in Table 1. Experiments R1 (ozone decreased by 15\%) and $\mathrm{R} 2$ (ozone increased by $15 \%$ ) are performed to see the effects of ozone within the observed range, and this ozone change is also similar to that in Xie et al. (2018) and Ma et al. (2019). Experiments R3 (ozone decreased by $25 \%$ ) and R4 (ozone increased by $25 \%$ ) are performed to see the effects of ozone with larger-amplitude change. More details of the numerical simulations are listed in Table 1. 
TABLE 1. Fully coupled CESM-WACCM4 experiments with various prescribed ozone forcings.

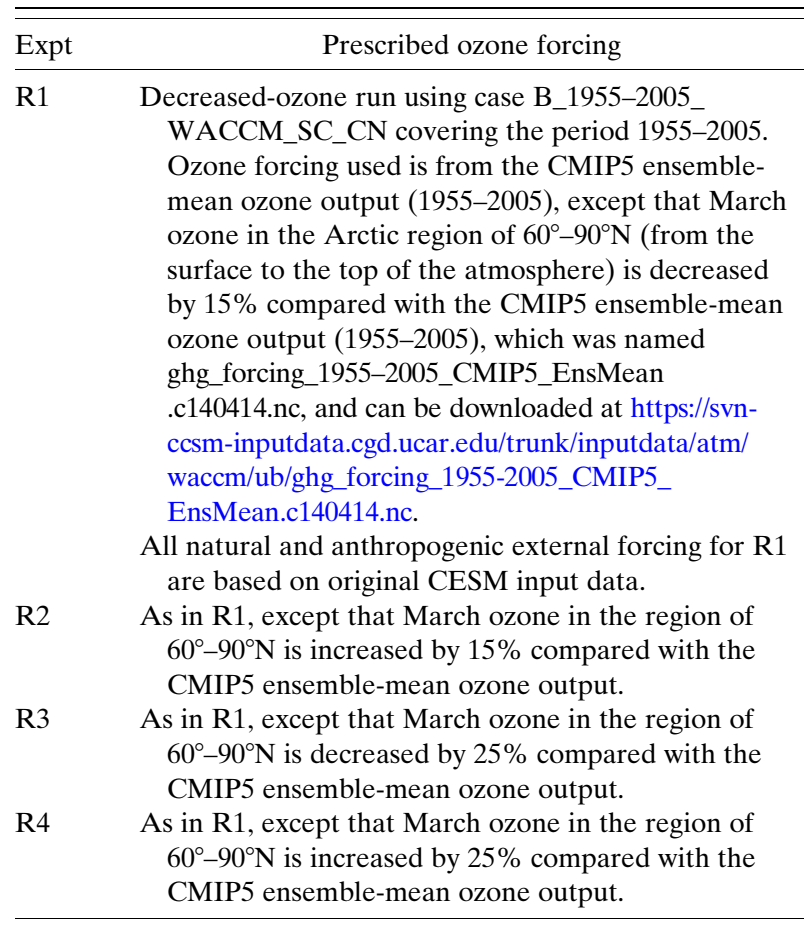

\section{c. Methods}

To analyze the propagation of Rossby waves, wave ray paths (e.g., Karoly 1983; Zhang et al. 2015) are calculated by solving the linear barotropic vorticity equation. In the mean flow $\bar{\psi}(x, y)$, the perturbation flow function satisfies

$$
\omega=\bar{u}_{M} k+\bar{v}_{M} l+\frac{(l \partial \bar{q} / \partial x-k \partial \bar{q} / \partial y)}{k^{2}+l^{2}},
$$

where $\omega$ is angular frequency; $\left(\bar{u}_{M}, \bar{v}_{M}\right)=[(\bar{u}, \bar{v}) / \cos \theta]$ represent the time-mean zonal wind and meridional wind under Mercator projection, respectively; $\theta$ represents latitude; $k$ and $l$ represent the zonal and meridional wavenumbers, respectively; and $\bar{q}$ represents the absolute vorticity. We can obtain four equations describing the group velocity $\left(u_{g}, v_{g}\right)$ and wavenumber $(k, l)$ (Karoly 1983), which can be integrated to obtain wave ray paths. The background flow field is obtained from the climatological (1979-2009)-mean wind field in May-June.

The Pacific decadal oscillation (PDO; Mantua et al. 1997; Zhang et al. 1997) and Victoria mode (VM; Bond et al. 2003) are the first and second mode of SSTAs over the North Pacific, respectively. According to the methods of Ding et al. (2015b), we calculate the first two modes (i.e., PDO and VM) of SSTAs over the North Pacific $\left(20.5^{\circ}-65.5^{\circ} \mathrm{N}, 124.5^{\circ} \mathrm{E}-100.5^{\circ} \mathrm{W}\right)$ in March by empirical orthogonal function (EOF) analysis.
To quantify the extent to which variations in the tropospheric circulation and SSTs over the western North Pacific in early summer (June) are explained by the Arctic TCO in March, we remove March SST signal from March Arctic TCO as shown in Eq. (2):

$$
\mathrm{TCO}(\text { resi })=\mathrm{TCO}-\mathrm{TCO}(\mathrm{SST}) \text {. }
$$

In Eq. (2), TCO represents the original time series of the Arctic TCO in March. TCO (SST) is obtained by the regression of March PDO $+\mathrm{VM}$ index onto March Arctic TCO. Thus, the residual component of TCO, namely, TCO(resi) is almost independent of March SSTs.

\section{Connections between Arctic TCO variations in March and the tropospheric circulation and SST changes over the western North Pacific in early summer}

Figure 2 shows the evolution of correlation coefficients between Arctic $\left(60^{\circ}-90^{\circ} \mathrm{N}\right)$ TCO in March and SSTs in March-August. Figure 2 indicates that the SSTAs in April (Fig. 2b) are similar to a positive VM, which is consistent with previous results (Xie et al. 2017a) that a decrease in the Arctic stratospheric ozone in March leads positive VM anomalies in April. Interestingly, the negative SSTAs over the western North Pacific $\left(25^{\circ}-40^{\circ} \mathrm{N}, 150^{\circ} \mathrm{E}-170^{\circ} \mathrm{W}\right)$ gradually weaken in May (Fig. 2c) but are suddenly enhanced and become statistically significant again in June (Fig. 2d). The amplitude of the negative SSTAs over the western North Pacific is strong, weak, and strong in April, May, and June (Figs. 2b-d), respectively. This phenomenon also exists in the MSR dataset and ERSSTv4 dataset (Figs. 2h-j), which supports the robustness of this phenomenon. It is reasonable to presume that underlying processes related to the Arctic TCO changes in March enhance the amplitude of the negative SSTAs over the western North Pacific in June. Therefore, it is necessary to investigate the effects of the Arctic TCO in March on the tropospheric circulation and SSTs over the western North Pacific in June.

Figure 3 shows the correlation coefficients between the Arctic TCO in March and geopotential height and wind in June. Both the TOMS/SBUV dataset and MSR dataset indicate that there exist an anomalous tropospheric cyclonic flow and negative geopotential height anomalies associated with the decrease in March Arctic TCO over the western North Pacific in June (Fig. 3). The results of ERA-Interim dataset (Figs. 3a,b) and NCEP2 dataset (Figs. 3c,d) are similar, which indicates that these connections between the Arctic TCO in March and the circulation over the western North Pacific in 
(a) Mar

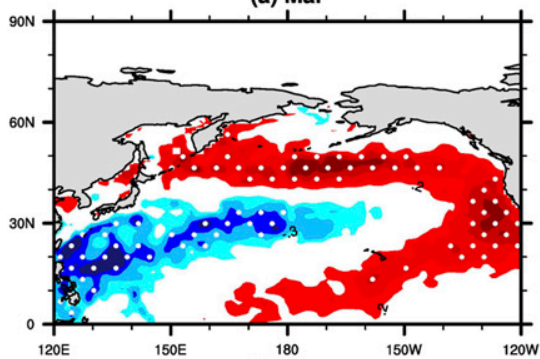

(d) Jun

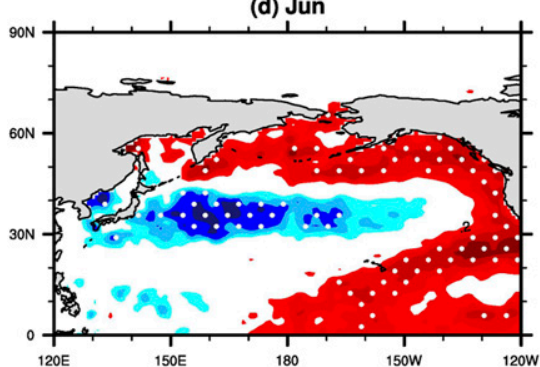

(g) Mar

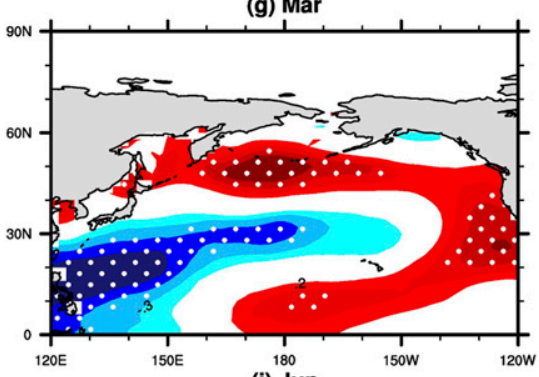

(j) Jun (b) Apr

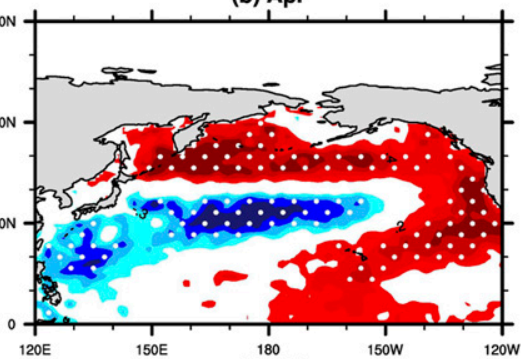

(e) Jul

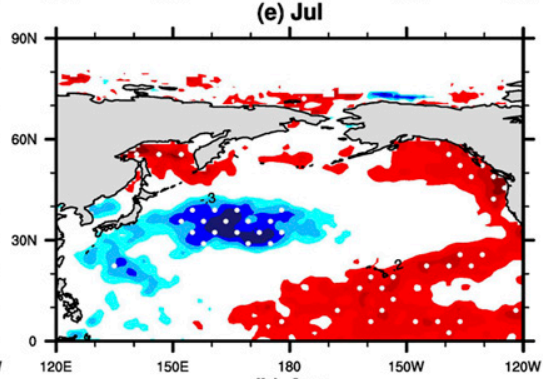

(h) Apr
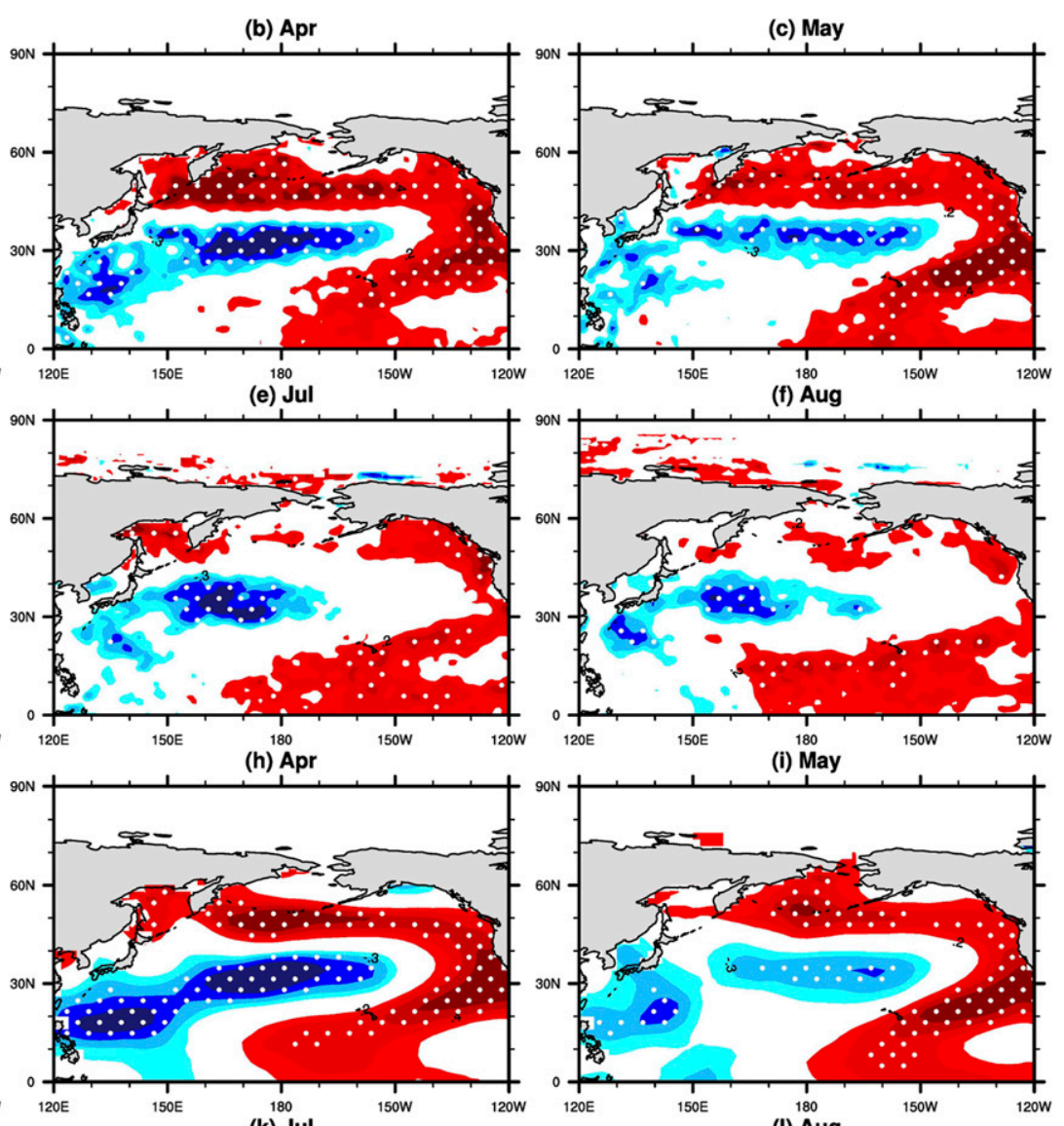

(f) Aug

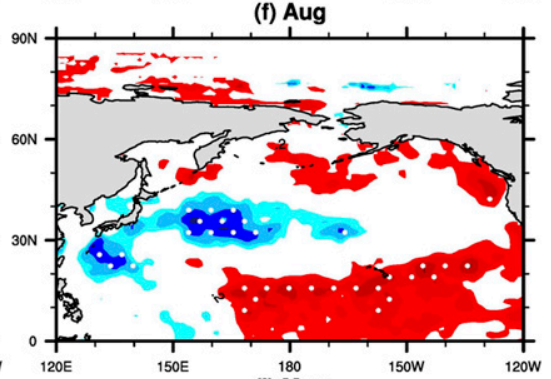

(i) May

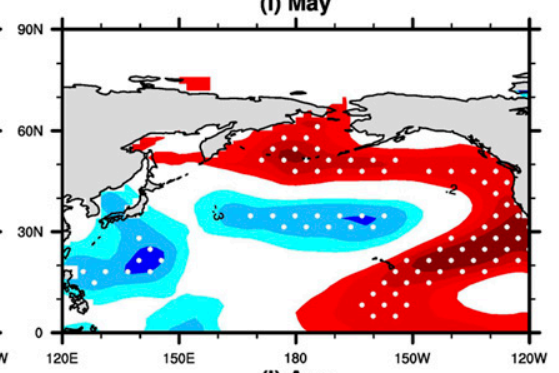

(I) Aug
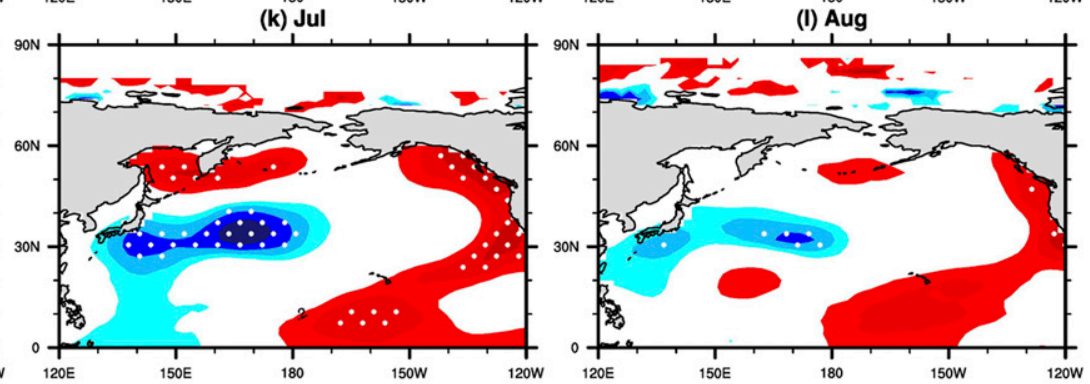

$-0.5$

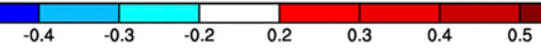

FIG. 2. Correlation coefficients between Arctic - TCO (TOMS/SBUV dataset) in March and sea surface temperature (HadSST) in (a) March, (b) April, (c) May, (d) June, (e) July, and (f) August. (g)-(l) As in (a)-(f), but the TCO data are from the MSR dataset and SST data are from the ERSSTv4 dataset. Stippled regions are statistically significant at the $95 \%$ confidence level according to the Student's $t$ test. The linear trends in all datasets have been removed.

June are reliable and not sensitive to dataset. Figure 4 shows the details of variations in the Arctic TCO in March and the upper-tropospheric geopotential height, lower-tropospheric geopotential height, and SSTs over the western North Pacific from April to June. There are close connections between the Arctic TCO in March and the upper-tropospheric geopotential height $(r=$ $0.61, p<0.01)$, lower-tropospheric geopotential height $(r=0.53, p<0.01)$, and SSTs $(r=0.47, p<0.01)$ over the western North Pacific in April (Figs. $4 \mathrm{a}-\mathrm{c}$ ), which are consistent with the results in Xie et al. (2017a) that a decrease in March Arctic ozone leads geopotential height anomalies similar to negative North Pacific Oscillation (NPO) and SSTAs similar to positive VM over the North Pacific in April. Gradually, these correlation coefficients weaken in May (Figs. 4d-f). However, the connections between the Arctic TCO in March and the upper-tropospheric geopotential height $(r=0.47$, $p<0.01)$, lower-tropospheric geopotential height $(r=$ $0.46, p<0.01)$, and SSTs $(r=0.55, p<0.01)$ are 
(a)TOMS/SBUV vs ERA-Interim $300 \mathrm{hPa}$

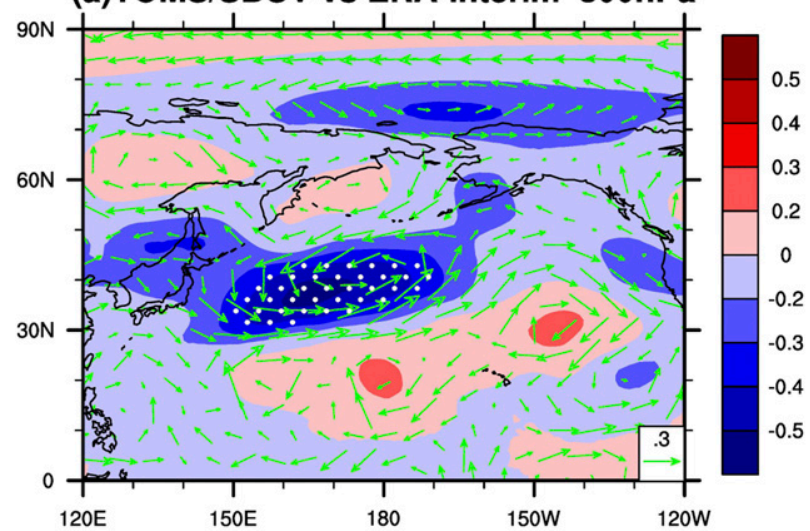

(c)MSR vs NCEP2 $300 \mathrm{hPa}$

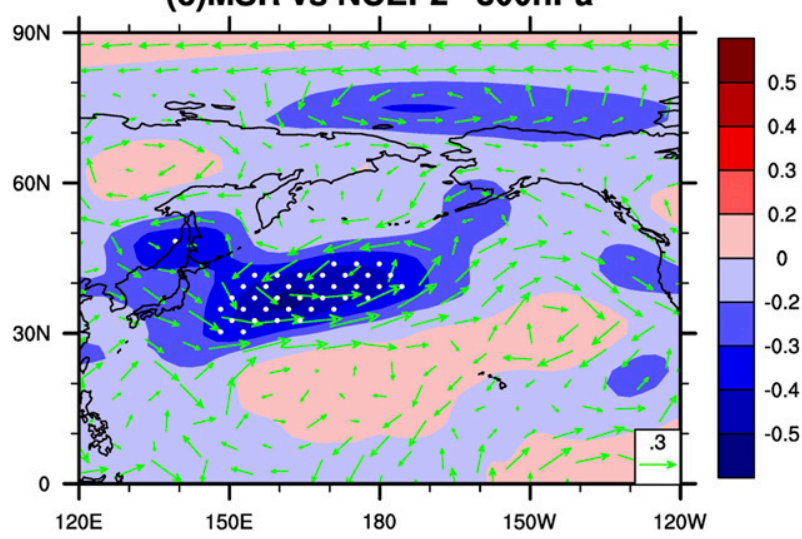

(b)TOMS/SBUV vs ERA-Interim 850hPa

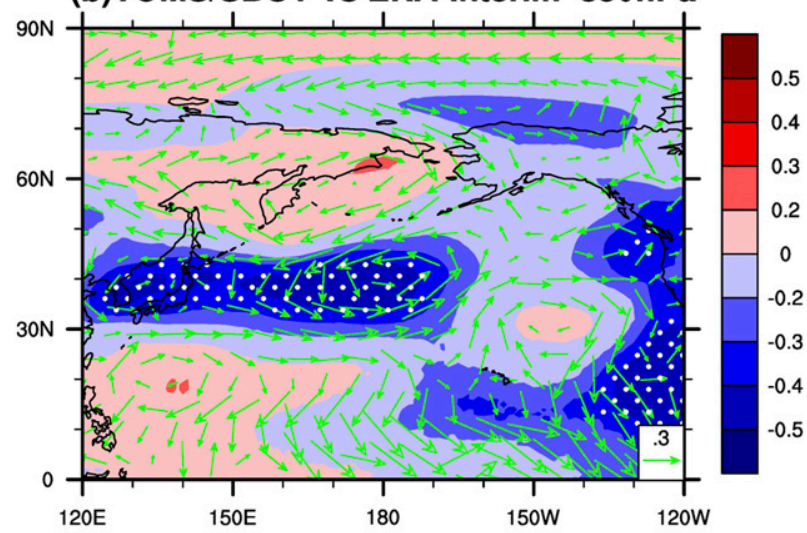

(d)MSR vs NCEP2 $850 \mathrm{hPa}$

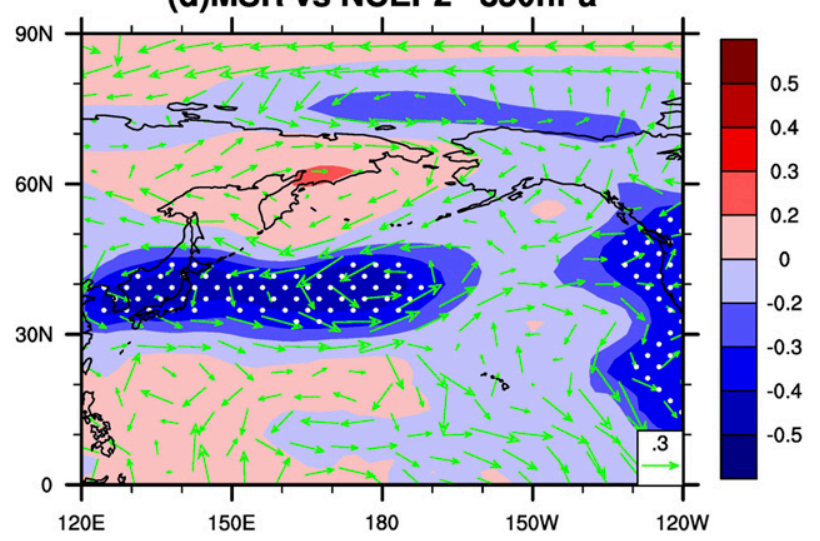

FIG. 3. (a) Correlation coefficients between Arctic - TCO in March and geopotential height (colors) and wind (vectors) at $300 \mathrm{hPa}$ in June. (b) As in (a), but for at $850 \mathrm{hPa}$. In (a) and (b), the TCO data are from TOMS/SBUV dataset and geopotential height and wind data are from ERA-Interim dataset. (c),(d) As in (a) and (b), but the TCO data are from MSR dataset and geopotential height and wind data are from the NCEP2 dataset. Dotted regions are statistically significant at the $95 \%$ confidence level.

enhanced and become statistically significant again in June (Figs. 4g-i).

The above results suggest close connections between the Arctic TCO in March and the tropospheric circulation and SSTs over the western North Pacific in June, and variations in the TCO lead variations in the circulation and SSTs by 3 months. These lead-lag connections suggest that changes in March Arctic TCO may affect the tropospheric circulation and SSTs over the western North Pacific in June. Therefore, a question arises as to what mechanism is responsible for these lead-lag connections. Considering that the results obtained from various datasets are similar, we only show the results of the TOMS/SBUV, ERA-Interim, and HadSST datasets in the following text.

Figure 5 displays temperature and circulation anomalies associated with the Arctic TCO in March. A decrease in the Arctic TCO in March corresponds to a colder and stronger stratospheric polar vortex (SPV; Figs. 5a-c), indicating that the decrease in the Arctic TCO strengthens the SPV through radiative processes (e.g., Ramaswamy et al. 1996; Hu et al. 2011). Furthermore, the positive zonal wind anomalies extend downward into the lower troposphere (Fig. 5c) through wave-mean flow interactions (e.g., Haynes et al. 1991; Song and Robinson 2004; Chen and Held 2007; Garfinkel and Hartmann 2011; Garfinkel et al. 2013). Note that correlation coefficients between March Arctic TCO and April and May Arctic TCO are $0.82(p<0.01)$ and $0.72(p<0.01)$, respectively, suggesting the autocorrelation of Arctic ozone. However, the stratospheric circulation anomalies associated with April-May Arctic TCO are relatively weak and do not extend downward into the troposphere (not shown), indicating that the circulation and SST anomalies over the western North Pacific in June (Figs. 2 and 3) should be linked to the March ozone rather than the April/May ozone. Xie et al. (2017a) indicated that the lowertropospheric positive zonal wind anomalies in the region $60^{\circ}-90^{\circ} \mathrm{N}, 180^{\circ}-120^{\circ} \mathrm{W}$ in March, caused by the decreased stratospheric ozone anomalies in March, contribute to negative North Pacific Oscillation anomalies in April. It is evident that there are statistically 
(a) Apr H300 ( $r=0.61 \mathrm{p}=0.000)$

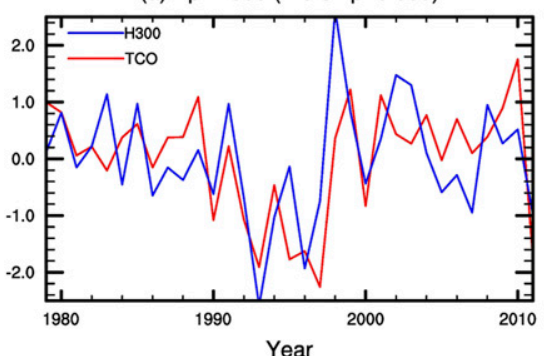

(d) May H300 ( $r=0.28 \mathrm{p}=0.117)$

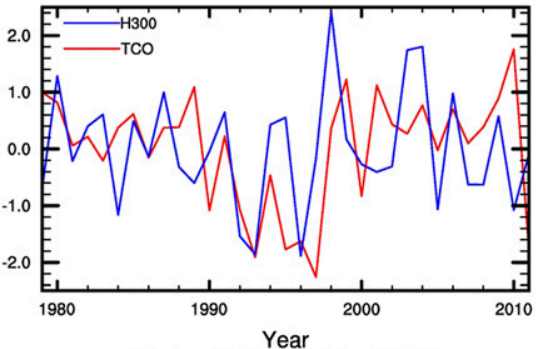

(g) Jun $\mathrm{H} 300(\mathrm{r}=0.47 \mathrm{p}=0.006)$

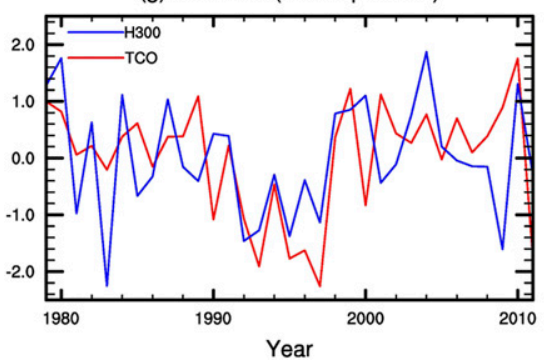

(b) Apr H850 (r=0.53 p=0.002)

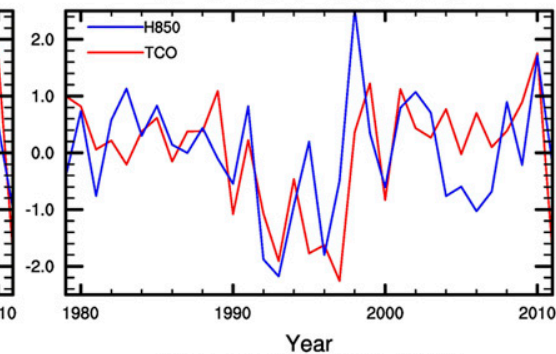

(e) May H850 ( $(r=0.18 \mathrm{p}=0.317)$

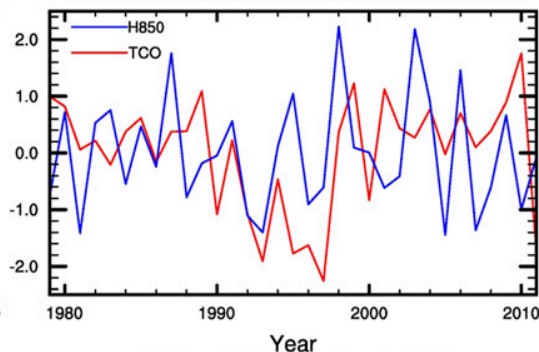

(h) Jun $\mathrm{H} 850(\mathrm{r}=0.46 \mathrm{p}=0.007)$

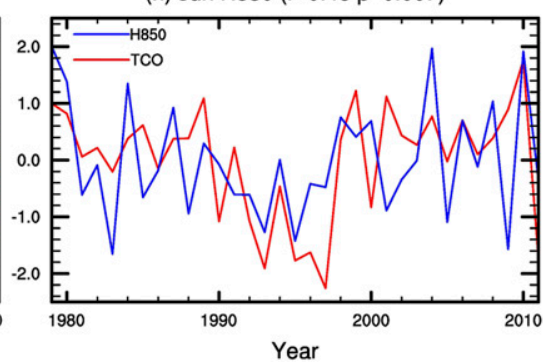

(c) Apr SST ( $r=0.47 \mathrm{p}=0.006)$

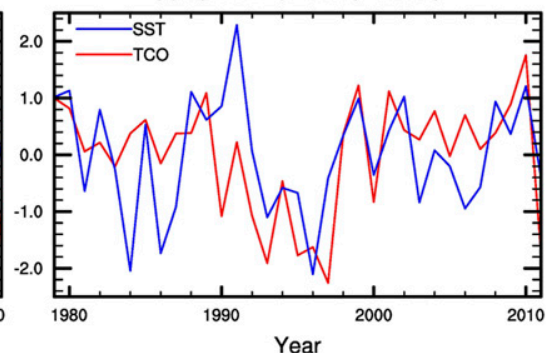

(f) May SST ( $r=0.44 p=0.011)$

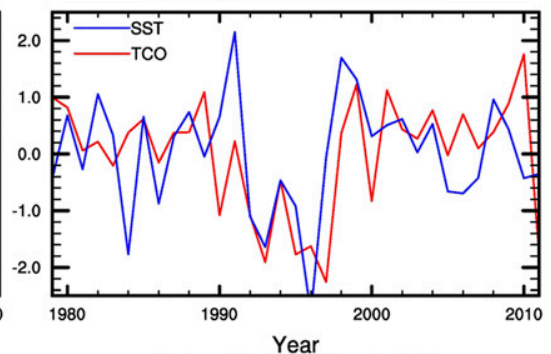

(i) Jun SST ( $r=0.55 \mathrm{p}=0.001)$

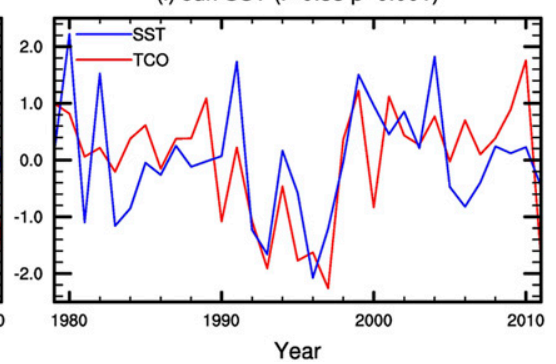

FIG. 4. Blue lines are detrended and standardized time series of (a),(d),(g) 300-hPa geopotential height (H300; averaged over $30^{\circ}-45^{\circ} \mathrm{N}$, $\left.130^{\circ} \mathrm{E}-180^{\circ}\right),(\mathrm{b}),(\mathrm{e}),(\mathrm{h}) 850-\mathrm{hPa}$ geopotential height $\left(\mathrm{H} 850\right.$; averaged over $\left.30^{\circ}-45^{\circ} \mathrm{N}, 130^{\circ} \mathrm{E}-180^{\circ}\right)$, and (c), (f), (i) sea surface temperature (SST; averaged over $30^{\circ}-40^{\circ} \mathrm{N}, 140^{\circ} \mathrm{E}-180^{\circ}$ ) in (a)-(c) April, (d)-(f) May, and (g)-(i) June. Red lines in (a)-(i) are the time series of Arctic TCO in March from the TOMS/SBUV dataset. The correlation coefficient $r$ between the red line and blue line in each panel is given in the title; $p$ is the confidence level and $r$ is statistically significant at the $99 \%$ confidence level when $p$ is less than 0.01 .

significant circulation anomalies at high latitudes in March (Fig. 5d) and negative NPO anomalies in April (Fig. 5e), which force positive VM anomalies (Fig. 2b). Here, we investigate how April SSTAs over North Pacific related to the Arctic TCO affect the circulation and SSTs over the western North Pacific in June.

Figure 6 shows the evolution of correlation coefficients between Arctic TCO in March and the lowertropospheric geopotential height, wind, and SSTs from April to June. The geopotential height anomalies similar to - NPO (Fig. 6d) and SST anomalies similar to + VM (Fig. 6a) are obvious and statistically significant in April. In addition, the April VM anomalies persist and develop into the next month (Fig. 6b) through atmosphereocean coupling (Xie and Philander 1994; Vimont et al. 2003; Song et al. 2016). Vimont et al. (2003) indicated that surface heating induced by the subtropical positive SSTAs over the eastern North Pacific leads to northward meridional flow over the positive
SSTA regions $\left(15^{\circ}-30^{\circ} \mathrm{N}, 160^{\circ}-120^{\circ} \mathrm{W}\right.$; Fig. $\left.6 \mathrm{~b}\right)$ and, in turn, the northward meridional flow enhances the local positive SSTAs. The northward meridional flow could further result in a surface cyclonic flow centered over the northern and western regions $\left(15^{\circ}-40^{\circ} \mathrm{N}\right.$, $160^{\circ}-120^{\circ} \mathrm{W}$; Figs. $\left.6 \mathrm{~b}, \mathrm{e}\right)$ of the subtropical positive SSTAs (Vimont et al. 2003). The features in Fig. 6b are also consistent with the results of Song et al. (2016, their Fig. 5b) describing the development of VM mode associated with an anomalous cyclone over the eastern North Pacific. In June, an anomalous cyclonic flow and enhanced negative SSTAs (Fig. 6c) occur over the western North Pacific compared to those in May.

Li et al. (2015, their Fig. 11) indicated that Rossby waves in the mid- to lower latitudes propagate westward in summertime lower troposphere. Therefore, it is reasonable that the anomalous cyclonic flow over the eastern North Pacific $\left(15^{\circ}-40^{\circ} \mathrm{N}, 160^{\circ}-120^{\circ} \mathrm{W}\right)$ in May (Figs. 6b,e), associated with the decrease in the Arctic 
(a) March T

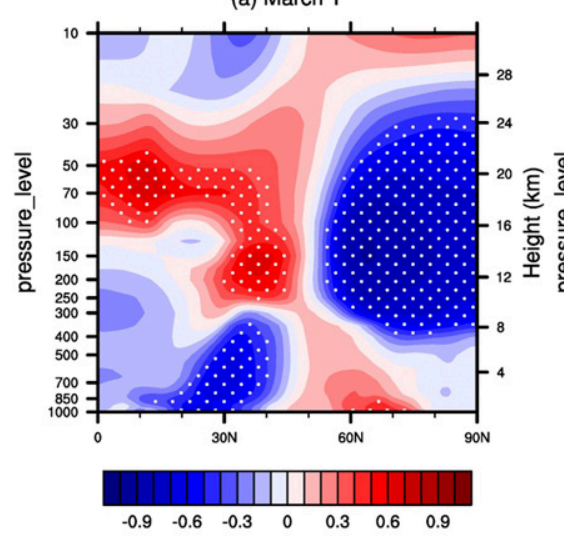

(b) March $\mathrm{H}$

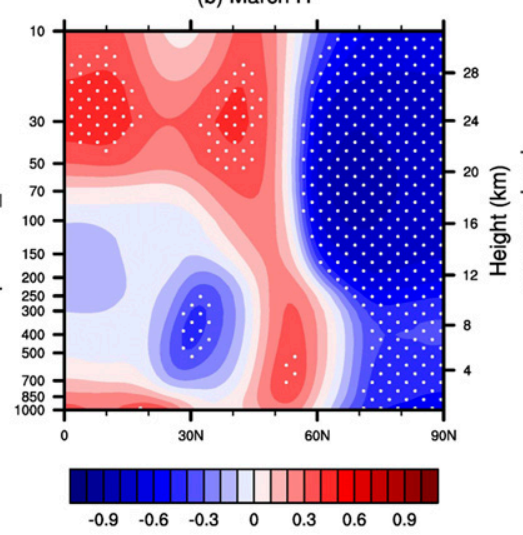

(c) March U

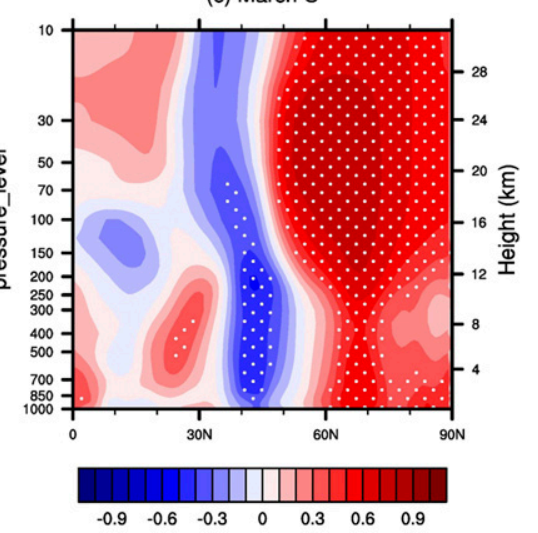

(d) March U

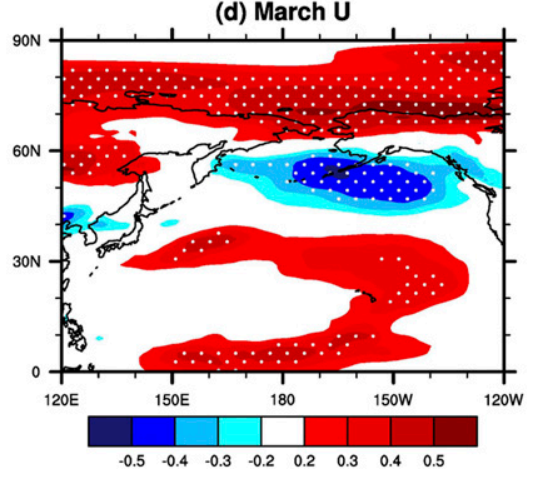

(e) April U

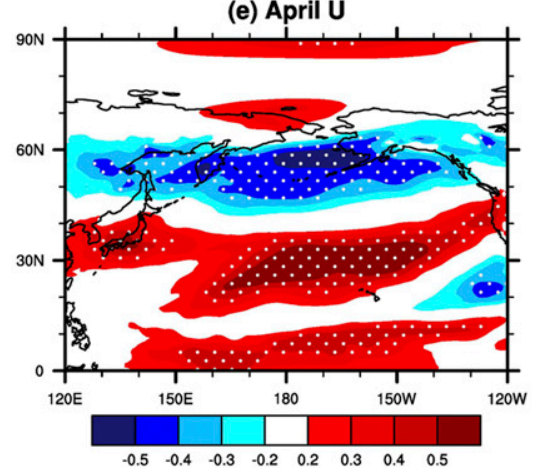

FIG. 5. Latitude-height cross section of correlation coefficients between Arctic-TCO in March and zonal-mean (a) temperature, (b) geopotential height, and (c) zonal wind in March. (d),(e) Correlation coefficients between Arctic - TCO in March and zonal wind at $850 \mathrm{hPa}$ in March and April, respectively. Stippled regions are statistically significant at the $95 \%$ confidence level.

TCO in March, could affect the circulation over the western North Pacific at a certain lag time through westward-propagating Rossby waves. Figure 7 indicates that the lower-tropospheric Rossby waves that originated from the eastern North Pacific will propagate to the western North Pacific approximately 1 month later along the anticyclone path. These results confirm that the cyclonic circulation anomalies over the eastern North Pacific in May (Figs. 6b,e) have an effect on circulation over the western North Pacific in the subsequent June (Figs. 6c,f). To further explore this lead-lag effect, we calculate correlation coefficients between the geopotential height averaged over the eastern Pacific $\left(30^{\circ}-35^{\circ} \mathrm{N}, 145^{\circ}-135^{\circ} \mathrm{W}\right)$ in May and geopotential height fields over the North Pacific in June as shown in Fig. 8. Figure 8 indicates that if there are negative geopotential height anomalies over the eastern North Pacific $\left(15^{\circ}-40^{\circ} \mathrm{N}, 160^{\circ}-130^{\circ} \mathrm{W}\right)$ in May (Fig. 8a), there will be negative geopotential height anomalies over the western North Pacific in the subsequent June (Fig. 8b). Therefore, Fig. 8 further indicates that the tropospheric circulation changes over the western North Pacific in June are strongly linked to the circulation anomalies over the eastern North Pacific in May. Figures 7 and 8 indicate that the anomalous cyclone over the eastern North Pacific in May (Figs. 6b,e) induces the anomalous cyclone over the western North Pacific in June (Figs. 6c,f). Furthermore, the anomalous northerly wind over the western North Pacific $\left(30^{\circ}-40^{\circ} \mathrm{N}, 140^{\circ} \mathrm{E}-\right.$ $180^{\circ}$; Figs. 3b,d or Fig. $6 \mathrm{c}$ ), associated with the anomalous cyclone, enhances the local negative SSTAs (Figs. 2d,j or Fig. 6c). Note that correlation coefficients between the Arctic TCO in March and net surface sensible and latent heat flux over the western North Pacific $\left(30^{\circ}-45^{\circ} \mathrm{N}, 130^{\circ} \mathrm{E}-170^{\circ} \mathrm{W}\right)$ in June are very small and not significant (not shown), suggesting that the effects of SSTAs in June over the western North Pacific on local atmosphere are weak.

Based on the above analysis, we propose a mechanism by which the Arctic TCO in March influences the circulation and SSTs over the western North Pacific in June. The mechanism includes the following processes: 1) A decrease in the Arctic TCO in March enhances the SPV (Fig. 5) and further induces negative NPO anomalies (Fig. 6d) and positive VM anomalies (Fig. 6a) in April, which has been clarified by a previous study 
(a) April

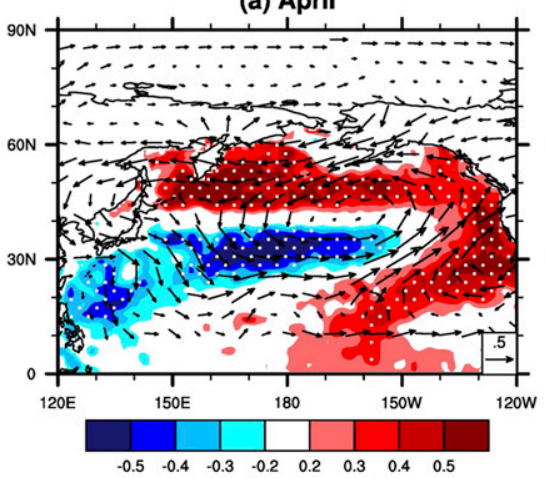

(d) April

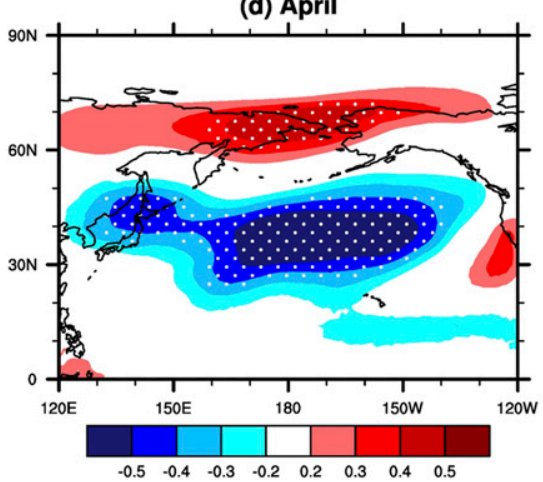

(b) May

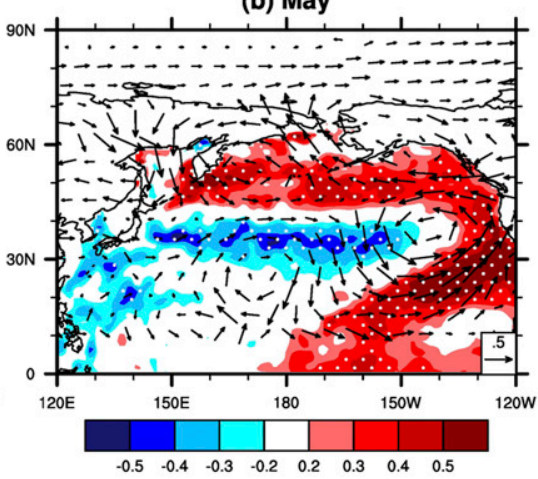

(c) June

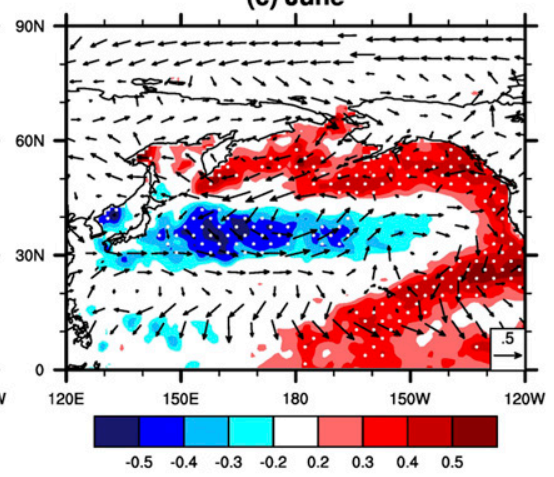

(e) May

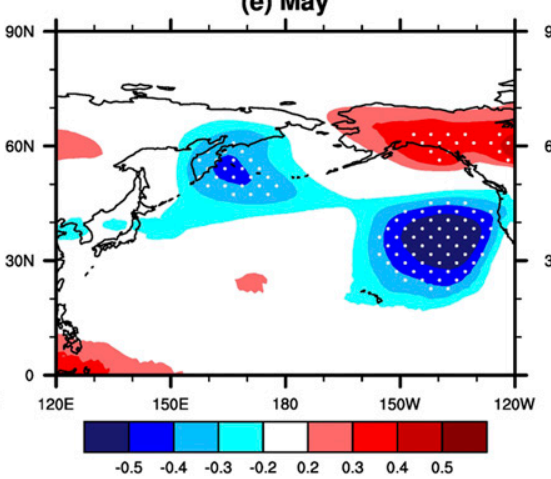

(f) June

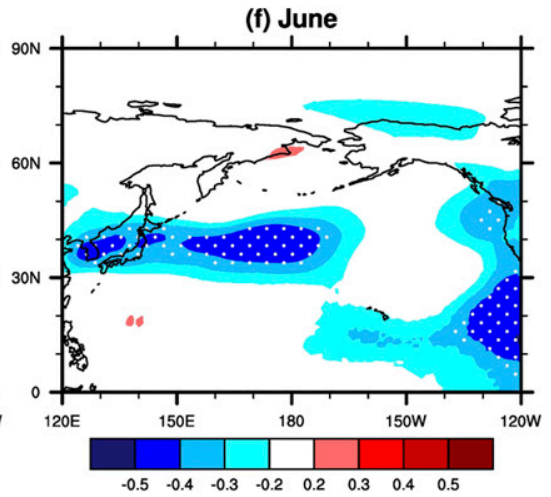

FIG. 6. Correlation coefficients between Arctic - TCO in March and (top) SST (colors) and winds (vectors) at $850 \mathrm{hPa}$ in (a) April, (b) May, and (c) June, and (bottom) geopotential height at $850 \mathrm{hPa}$ in (d) April, (e) May, and (f) June. Stippled regions are statistically significant at the $95 \%$ confidence level.

(Xie et al. 2017a). 2) The April SSTAs associated with the decrease in Arctic TCO in March persist and develop an anomalous cyclone over the eastern North Pacific $\left(15^{\circ}-40^{\circ} \mathrm{N}, 160^{\circ}-120^{\circ} \mathrm{W}\right)$ in May (Figs. 6b,e) through atmosphere-ocean coupling (e.g., Vimont et al. 2003; Song et al. 2016). 3) This anomalous cyclone (Figs. 6b,e) further leads to an anomalous cyclone over the western North Pacific in June (Figs. 6c,f) by westward-propagating Rossby waves in the lower troposphere, which would take approximately 1 month (Figs. 7 and 8). Furthermore, the anomalous northerly wind over the western North Pacific $\left(30^{\circ}-40^{\circ} \mathrm{N}, 140^{\circ} \mathrm{E}-\right.$ $180^{\circ}$; Figs. 3b,d or Fig. $6 \mathrm{c}$ ) associated with the anomalous cyclone enhances the local negative SSTAs (Figs. 2d,j or Fig. 6c). The effects of an increase in Arctic TCO in March are almost opposite to those of a decrease in March Arctic TCO.

\section{Simulated variations in circulation and SSTs forced by spring Arctic ozone anomalies}

In this section, we use numerical simulations to verify the results obtained from the reanalysis data. The model and experiments are introduced in section 2. Figure 9 shows the ozone forcing prescribed in experiments R1-R4. Figure 10 shows the geopotential height and SST differences between experiments R1 (ozone decreased by $15 \%$ ) and R2 (ozone increased by $15 \%$ ). It is apparent that a $15 \%$ stratospheric ozone decrease induces negative SST anomalies over the middle North Pacific $\left(20^{\circ}-30^{\circ} \mathrm{N}, 120^{\circ} \mathrm{E}-150^{\circ} \mathrm{W}\right)$ and positive SST anomalies over the northern, eastern, and southern North Pacific in April (Fig. 10a), which is similar to the VM. The pattern of geopotential height in April is similar to NPO (Fig. 10d), with a negative center over southern regions $\left(15^{\circ}-35^{\circ} \mathrm{N}, 160^{\circ} \mathrm{E}-150^{\circ} \mathrm{W}\right)$ of the North Pacific and a positive center over the northern regions $\left(40^{\circ}-60^{\circ} \mathrm{N}, 160^{\circ} \mathrm{E}-140^{\circ} \mathrm{W}\right)$. Although the centers of the NPO and VM in Figs. 10a and 10d are located farther south than those in the reanalysis dataset (Figs. 6a,d), their patterns are overall similar. Figures 10a and 10d support the result that the stratospheric ozone decrease in March could induce NPO and VM anomalies over the North Pacific in April.

Comparing experiments R1 and R2, the model cannot capture the ozone-related negative geopotential height anomalies and the enhanced negative SSTs over the western North Pacific in June as exhibited in the 

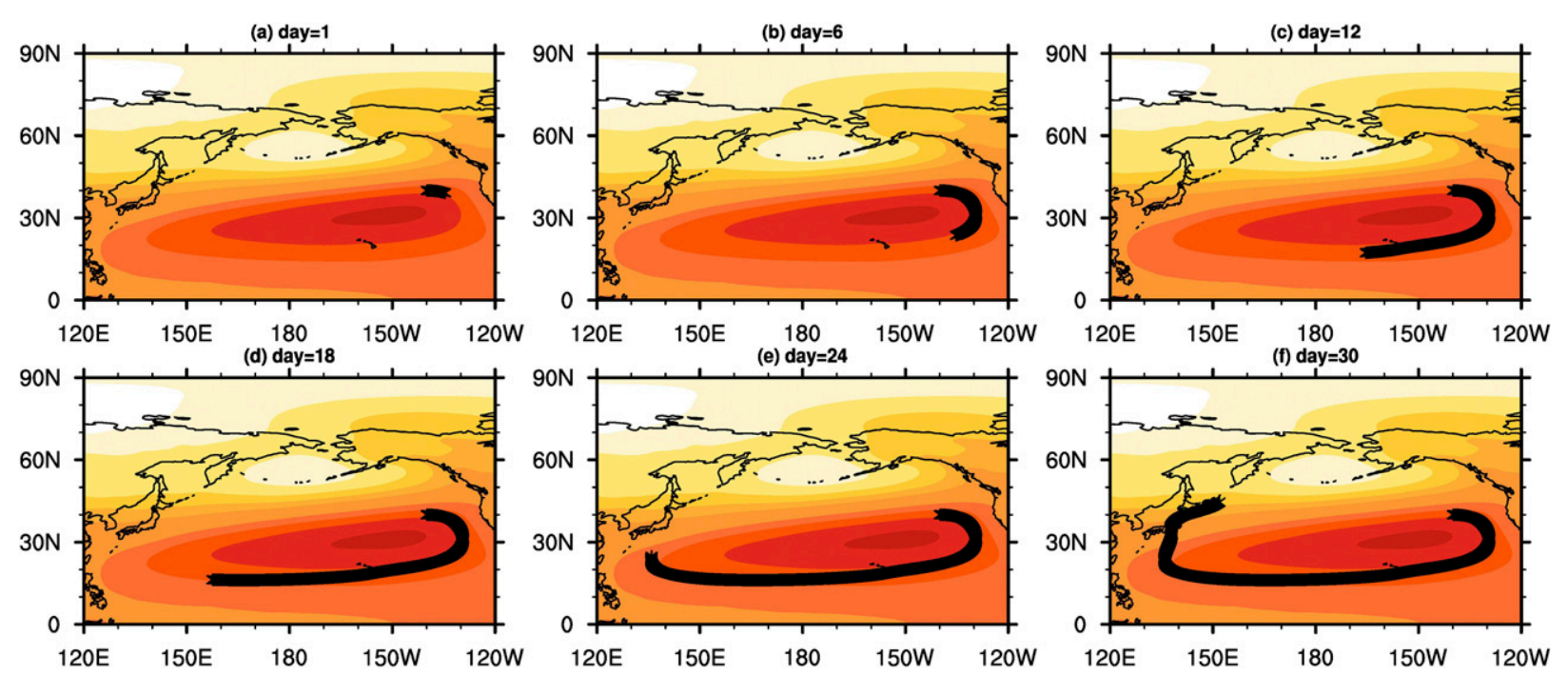

FIG. 7. Ray paths (coarse black lines) of Rossby waves (wavenumber 1) at $850 \mathrm{hPa}$. The wave source is over the eastern North Pacific $\left(40^{\circ} \mathrm{N}, 140^{\circ} \mathrm{W}\right)$. Panels are shown at day (a) 1 , (b) 6 , (c) 12 , (d) 18 , (e) 24 , and (f) 30 . Colored regions indicate the distribution of the climatological (1979-2009)-mean geopotential height (gpm) at $850 \mathrm{hPa}$ in May-June. The red and white regions represent high and low geopotential height, respectively.

reanalysis data (Figs. 6c,f). This may be because the differences in VM anomaly between experiments R1 and R2 are weak (Fig. 10a). In particular, positive SSTAs over the eastern North Pacific regions $\left(10^{\circ}-30^{\circ} \mathrm{N}\right.$, $160^{\circ}-120^{\circ} \mathrm{W}$; Fig. $\left.10 \mathrm{a}\right)$ are weak so that the development of the cyclonic circulation anomaly over the eastern North Pacific $\left(10^{\circ}-30^{\circ} \mathrm{N}, 160^{\circ}-120^{\circ} \mathrm{W}\right)$ (Figs. $\left.10 \mathrm{~b}, \mathrm{e}\right)$, which is a key process that induces the cyclonic circulation anomaly and enhanced negative SST anomalies over the western North Pacific in June as shown in Figs. $6 \mathrm{~b}$ and $6 \mathrm{e}$, is not prominent. Therefore, the anomalous cyclonic flow and enhanced negative SST anomalies over the western North Pacific in June are also not reproduced by the model experiments (Figs. 10c,f). Thus, we performed another two numerical experiments (R3 and R4) to see if a larger ozone decrease can induce the circulation and SST anomalies in June.

Figure 11 shows the geopotential height and SST differences between experiments R3 (ozone decreased by $25 \%$ ) and R4 (ozone increased by $25 \%$ ). Similar to the results of experiments R1 and R2, there are still ozone-induced NPO and VM anomalies over the North Pacific in April (Figs. 11a,d), and the SST differences (Fig. 11a) are larger than that in experiments R1 and R2 (a) May H $850 \mathrm{hPa}$

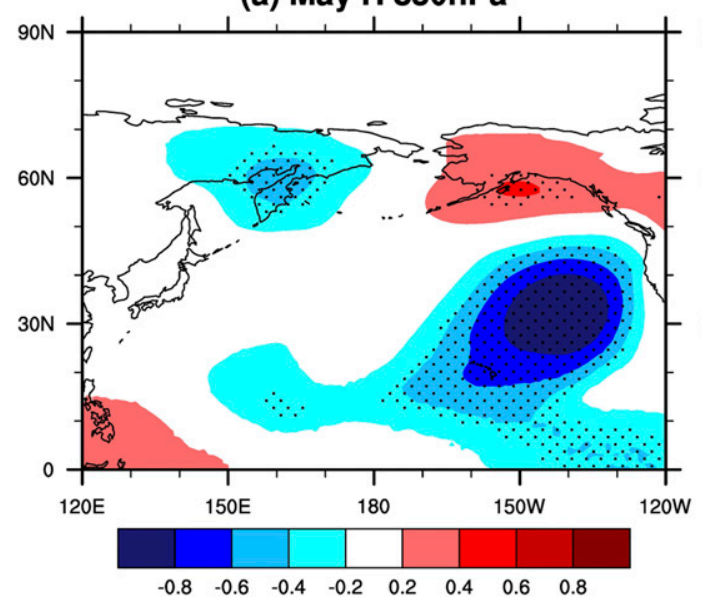

(b) Jun $\mathrm{H} 850 \mathrm{hPa}$

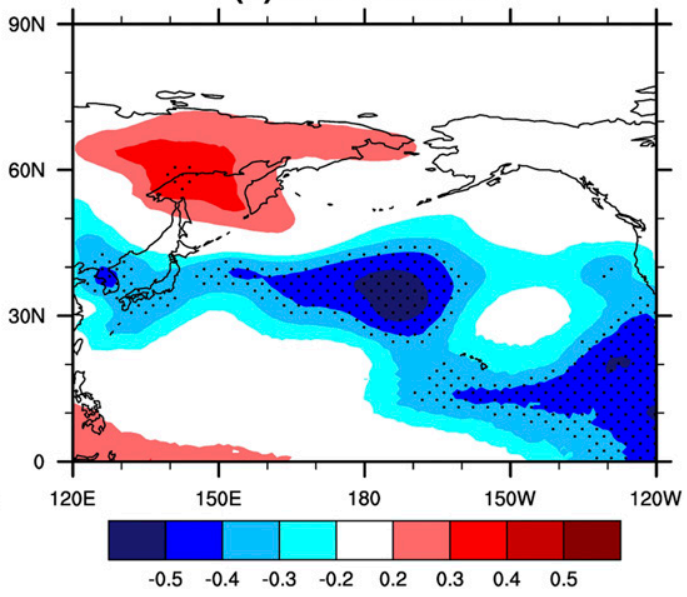

FIG. 8. Correlation coefficients between $-H$ (geopotential height averaged over $30^{\circ}-35^{\circ} \mathrm{N}, 145^{\circ}-135^{\circ} \mathrm{W}$ ) at $850 \mathrm{hPa}$ in May and geopotential height at $850 \mathrm{hPa}$ in (a) May and (b) June. Stippled regions are statistically significant at the $95 \%$ confidence level. 


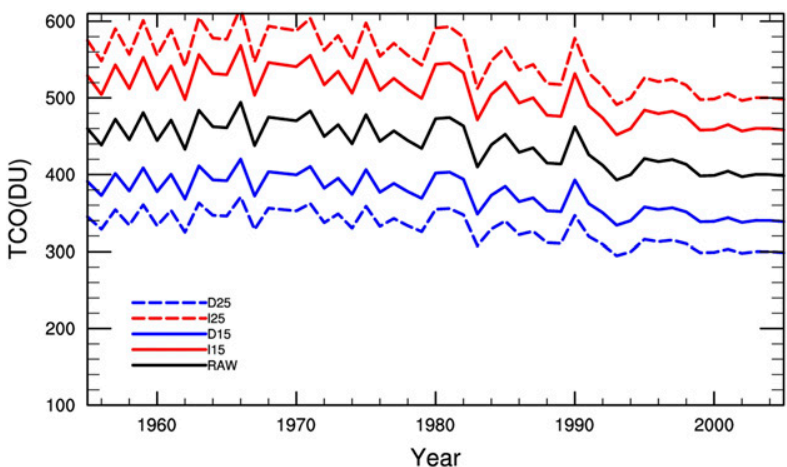

FIG. 9. Prescribed ozone forcing used in the numerical simulations. The blue solid line, red solid line, blue dashed line, and red dashed line are March Arctic $\left(60^{\circ}-90^{\circ} \mathrm{N}\right)$ TCO prescribed in experiments R1, R2, R3, and R4, respectively. The black line is for CMIP5 ensemble-mean ozone output.

(Fig. 10a). Furthermore, these experiments can capture the development of the anomalous cyclone over the eastern North Pacific $\left(20^{\circ}-40^{\circ} \mathrm{N}, 180^{\circ}-140^{\circ} \mathrm{W}\right)$ in May (Figs. 11b,e) induced by the ozone decrease and the subsequent ozone-induced anomalous cyclone over the western North Pacific $\left(30^{\circ}-50^{\circ} \mathrm{N}, 120^{\circ}-140^{\circ} \mathrm{E}\right)$ in June (Figs. 11c,f), supporting the results in reanalysis data that the VM anomaly associated with March Arctic ozone induces an anomalous cyclone over the western North Pacific in June (Figs. 6c,f). Note that the negative SST anomalies over the western North Pacific $\left(30^{\circ}-50^{\circ} \mathrm{N}\right.$, $130^{\circ} \mathrm{E}-180^{\circ}$ ) in June (Fig. 11c) are not enhanced compared to that in May (Fig. 11b), which may be because the position of the anomalous cyclone is farther west $\left(30^{\circ}-50^{\circ} \mathrm{N}, 120^{\circ}-140^{\circ} \mathrm{E}\right.$, Fig. 11f) than those in the reanalysis data (Fig. 6f).

Figure 10 suggests that the simulation with a $15 \%$ ozone decrease reproduces a too-weak VM anomaly in April (Fig. 10a) to induce the anomalous cyclone over the western North Pacific in June, which may be related to the limitation in model ability to simulate the air-sea feedback processes over North Pacific. However, when the amplitude of ozone change is increased to $25 \%$, the model could reproduce a large VM anomaly in April (Fig. 11a) and the subsequent anomalous cyclones in May and June (Figs. 11e,f), which are similar to that in the reanalysis data (Fig. 6). Both Figs. 10 and 11 indicate that stratospheric ozone changes in March contribute to the VM anomaly over the North Pacific in April, and Fig. 11 further supports the rationality of the mechanism proposed in this study. (a) April

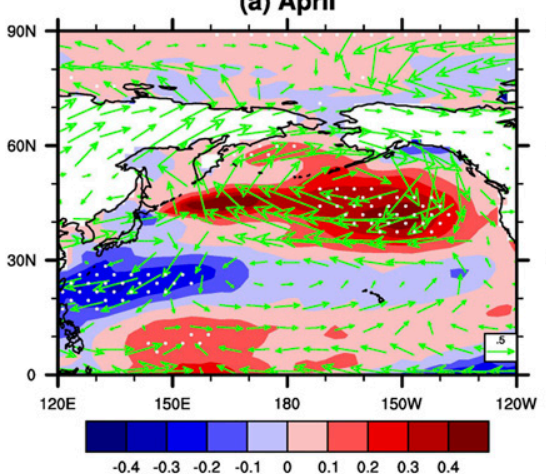

(d) April

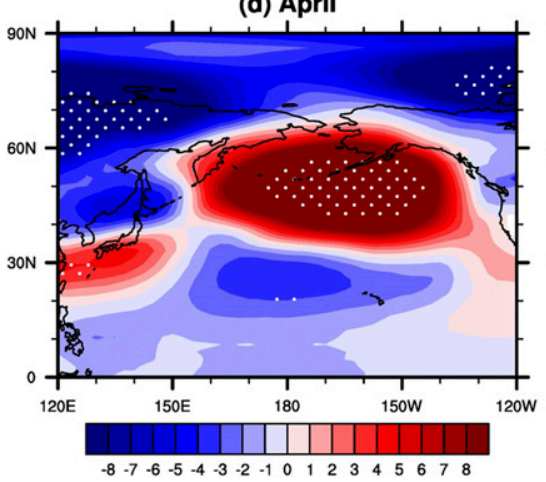

(b) May

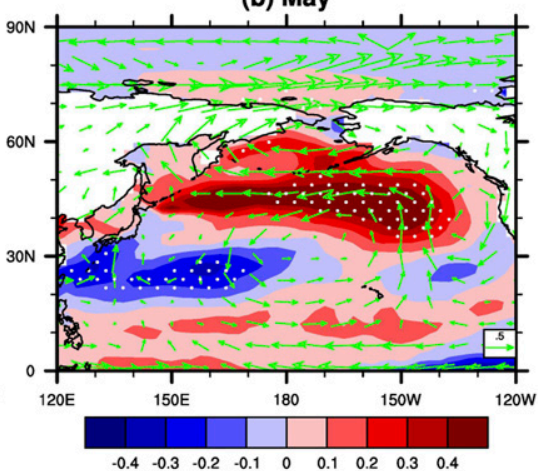

(e) May

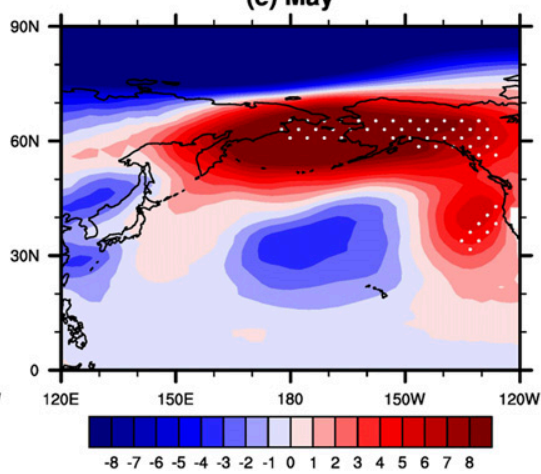

(c) June

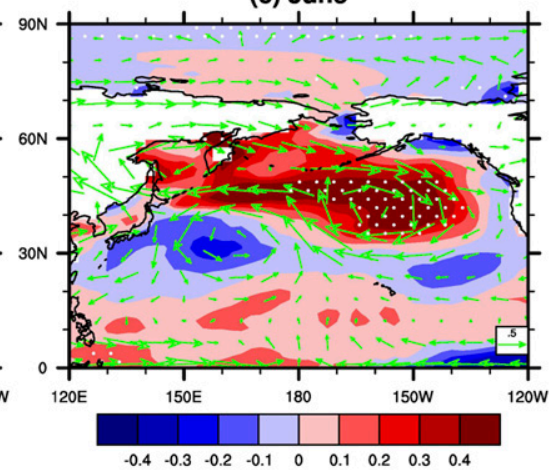

(f) June

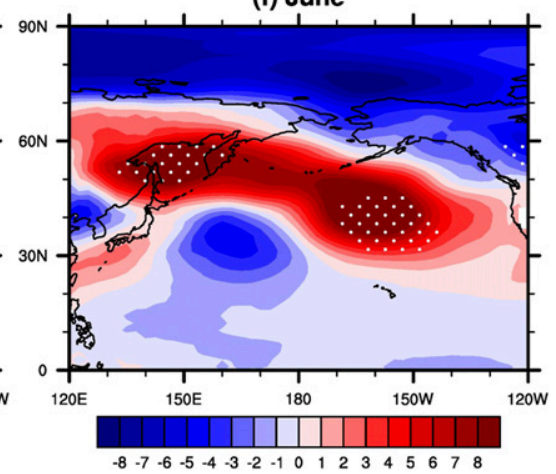

FIG. 10. (top) SST (colors) and horizontal wind ( $850 \mathrm{hPa}$; vectors) differences between experiments R1 (ozone decreased by $15 \%$ ) and R2 (ozone increased by 15\%) in (a) April, (b) May, and (c) June. (bottom) Geopotential height ( $850 \mathrm{hPa}$ ) difference between experiments R1 and R2 in (d) April, (e) May, and (f) June. Stippled regions are statistically significant at the $90 \%$ confidence level. 
(a) April

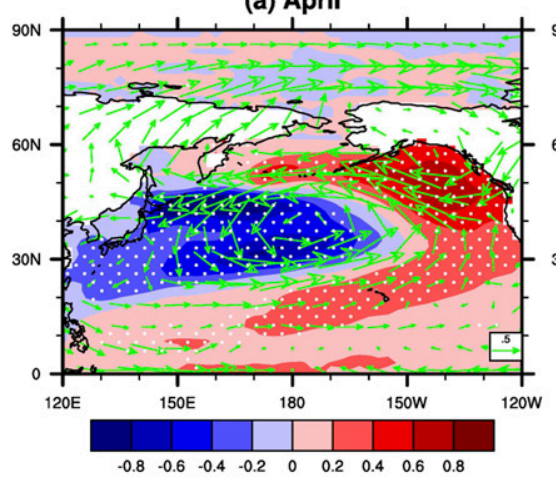

(d) April

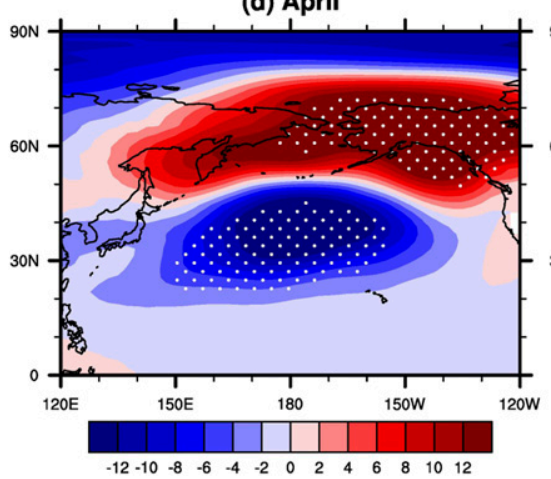

(b) May

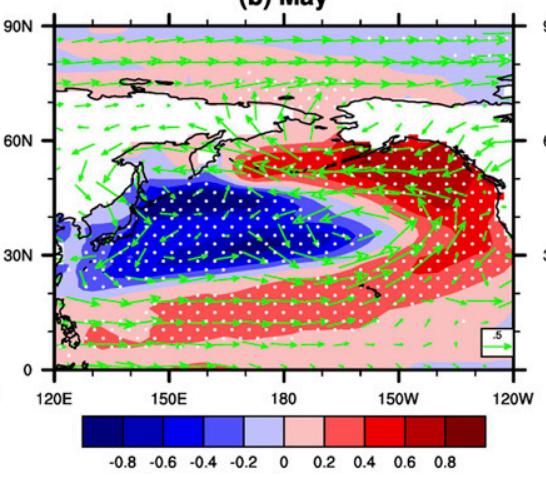

(e) May

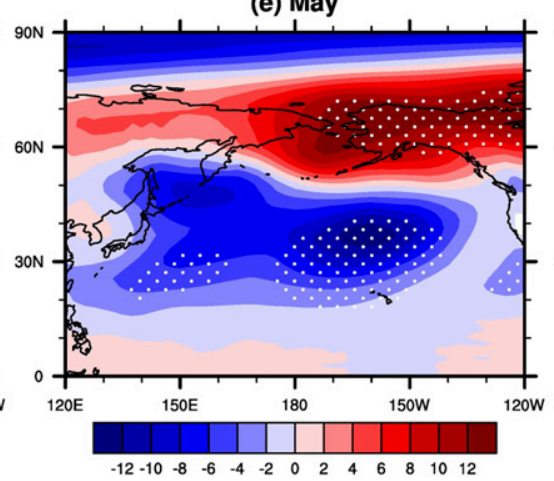

(c) June

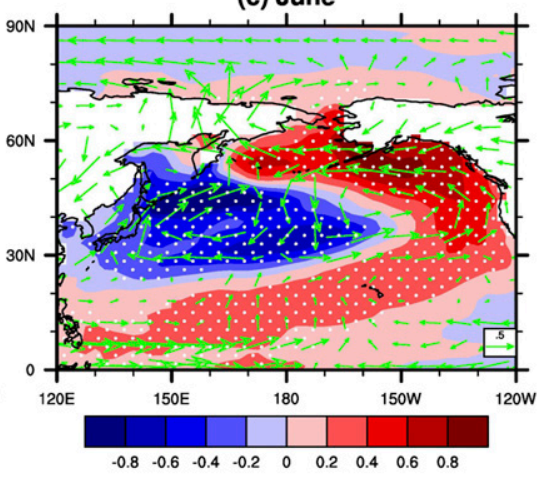

(f) June

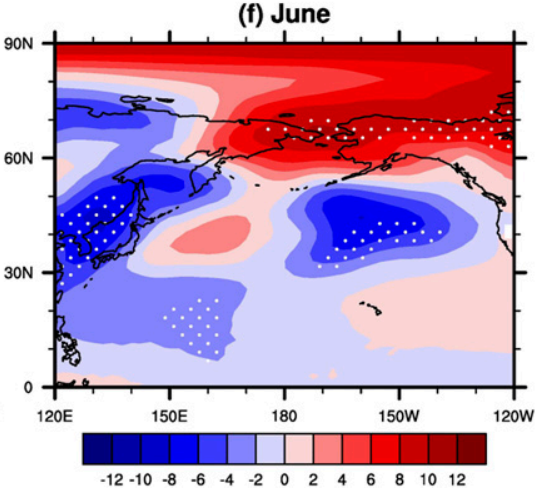

FIG. 11. As in Fig. 10, but for differences between experiments R3 (ozone decreased by 25\%) and R4 (ozone increased by $25 \%$ ).

\section{Contribution of the Arctic TCO variations in March to changes in the circulation and SSTs over the western North Pacific in early summer}

In this section, we quantify the extent to which the variation in the tropospheric circulation and SSTs over the western North Pacific in early summer (June) could be explained by the Arctic TCO in March. Note that there likely exists a bidirectional connection in March between the Arctic TCO and the SSTs over the North Pacific; that is, the SSTs in March (Fig. 2a) may affect stratospheric ozone. Therefore, we check the relationship in March between SST and Arctic TCO. The spatial patterns of PDO and VM are shown in Figs. 12a and 12b, respectively. It is found that correlation coefficients between the Arctic TCO in March and PDO and VM are $-0.36(p<0.05)$ and $-0.39(p<0.05)$, respectively (Figs. 12c,d). The correlation coefficient between the Arctic TCO and PDO + VM is $-0.53(p<0.01)$. The statistically significant correlation coefficient in March between Arctic TCO and SSTs is likely linked to the effects of North Pacific SSTs on the stratospheric polar vortex (Jadin et al. 2010; Hurwitz et al. 2012; Garfinkel et al. 2015; Woo et al. 2015; Kren et al. 2016; Hu et al. 2018; Hu and Guan 2018) and thereby the Arctic TCO (e.g., Schoeberl and Hartmann 1991). Therefore, to accurately estimate the extent to which the variations in the tropospheric circulation and SSTs over the western North Pacific in June are explained by the Arctic TCO changes in March, we first remove March SST signal from March Arctic TCO using a linear regression model as shown in Eq. (2).

Figure 13 shows the correlation coefficients between the TCO(resi) in March and the tropospheric circulation and SSTs over the western North Pacific in June. Although the correlation coefficients are smaller than those in Figs. 2 and 3, statistically significant negative correlation coefficients still exist over the western North Pacific (Figs. 13a-c), which further indicates that a decrease in the Arctic TCO in March leads to the tropospheric cyclonic circulation anomalies and negative SSTAs over the western North Pacific in June and vice versa. Moreover, $10 \%-20 \%$ of the variations in the tropospheric circulation and SSTs over the western North Pacific in June are affected by the Arctic TCO variations in March (Figs. 13d-f).

\section{Conclusions and discussions}

In this study, various observations, reanalysis datasets, and a general circulation model (CESM-WACCM4) were used to probe the potential connections between 
(a) EOF1

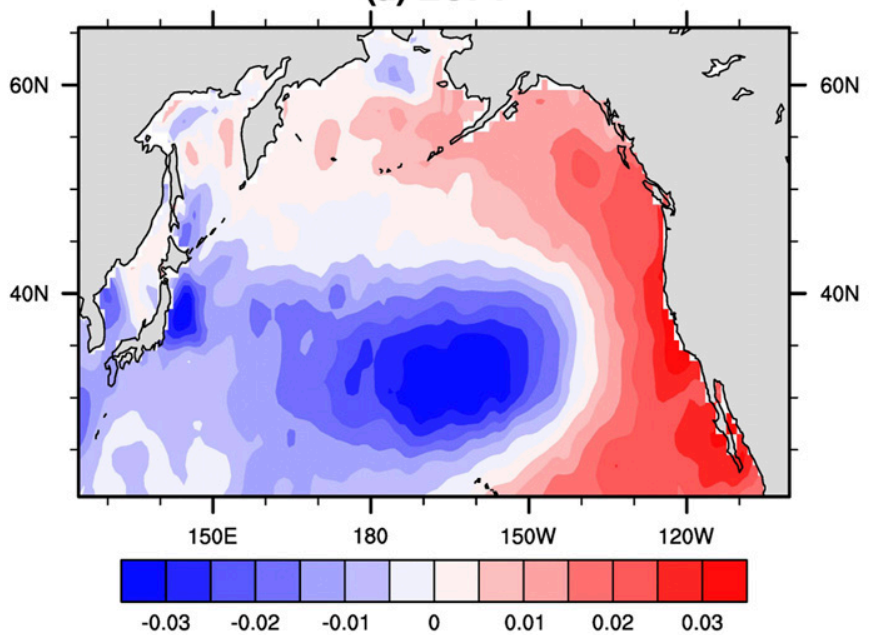

(c) $-\mathrm{PC} 1$

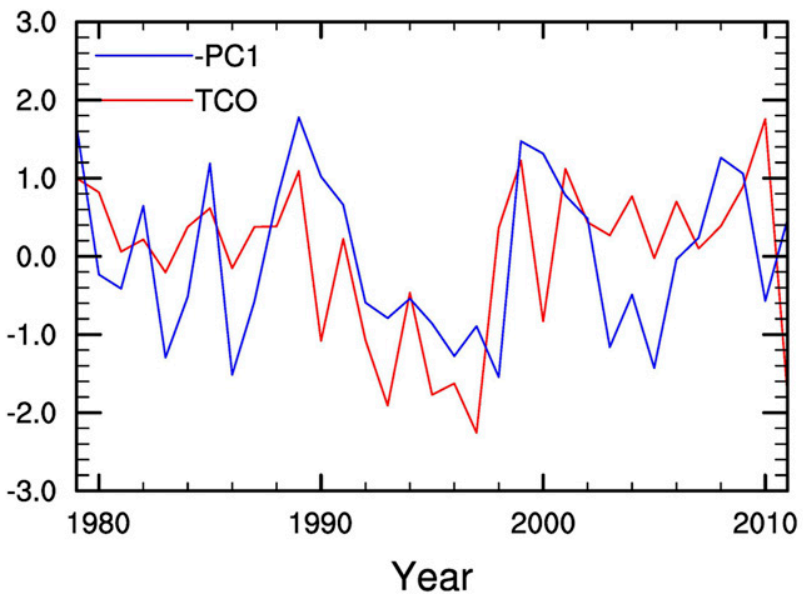

(b) EOF2

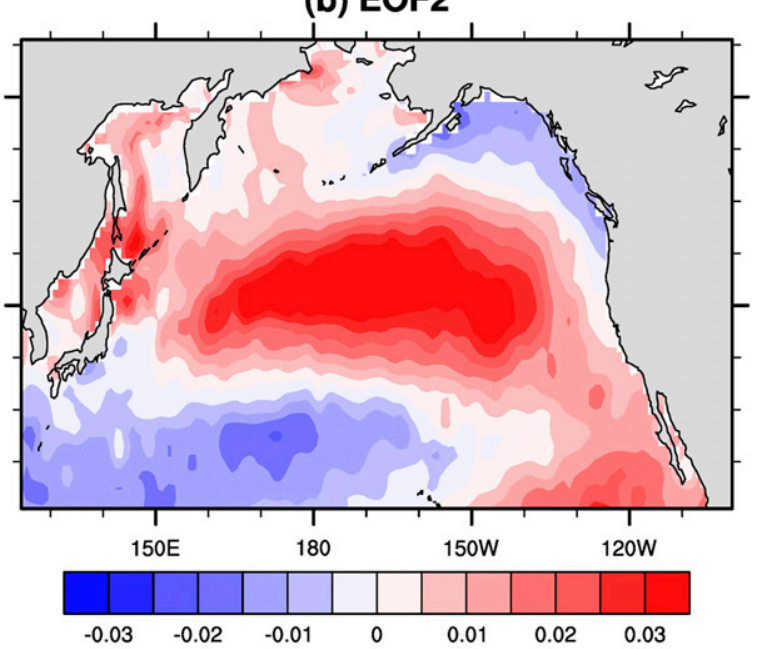

(d) -PC2

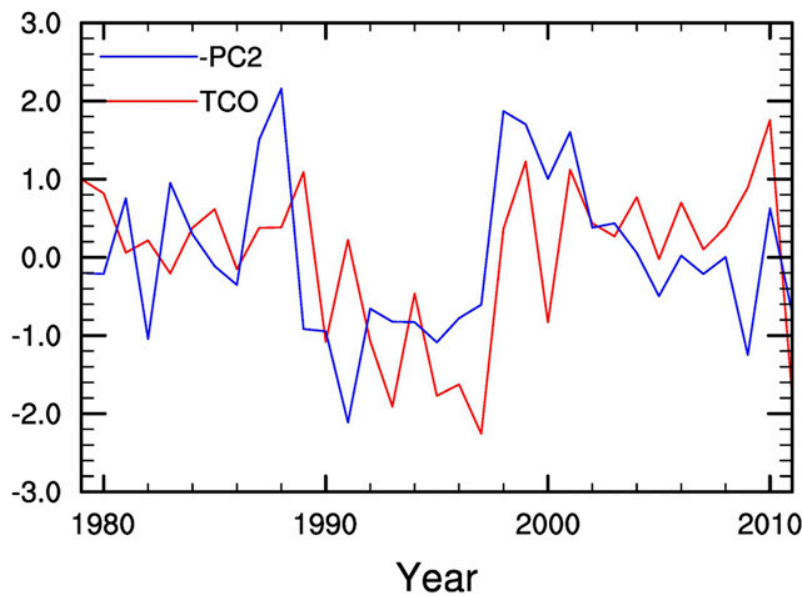

FIG. 12. The spatial patterns of the (a) EOF1 (PDO) mode and (b) EOF2 (VM) mode of SSTA field (after removing the globally averaged SSTAs) over the North Pacific $\left(20.5^{\circ}-65.5^{\circ} \mathrm{N}, 124.5^{\circ} \mathrm{E}-100.5^{\circ} \mathrm{W}\right)$ in March. Variances explained by the EOF1 and EOF2 modes are $33.3 \%$ and $16.7 \%$, respectively. Also shown are detrended and standardized time series of (c) Arctic TCO and PC1 and (d) Arctic TCO and PC2 in March. The signs of PC1 and PC2 are reversed to facilitate direct comparison. The correlation coefficients between TCO and $\mathrm{PC} 1$ and $\mathrm{PC} 2$ are $-0.36(p<0.05)$ and $-0.39(p<0.05)$, respectively.

TCO variations and the tropospheric circulation and SST changes. We found that the tropospheric cyclonic circulation anomalies and negative SSTAs over the western North Pacific $\left(30^{\circ}-45^{\circ} \mathrm{N}, 130^{\circ} \mathrm{E}-170^{\circ} \mathrm{W}\right)$ in June are closely linked to the decrease in Arctic TCO in March and vice versa. In addition, variations in the Arctic TCO in March lead the changes in the tropospheric circulation and SSTs over the western North Pacific by 3 months.

We further analyzed the underlying mechanism responsible for the lead-lag correlations between the Arctic TCO in March and the tropospheric circulation and SSTs over the western North Pacific in June. The main mechanisms are as follows: 1) A decrease in the
Arctic TCO in March strengthens the stratospheric polar vortex (Figs. 5a-c) and further induces negative NPO anomalies (Fig. 6d) and positive Victoria mode (VM) anomalies (Fig. 6a) in April, which are consistent with previous study (Xie et al. 2017a). Subsequently, the April VM anomaly associated with the decrease in the Arctic TCO in March persists and develops an anomalous cyclone over the eastern North Pacific in May (Figs. 6b,e) through atmosphere-ocean coupling. 2) This anomalous cyclone over the eastern North Pacific in May (Figs. 6b,e) further causes an anomalous cyclonic flow over the western North Pacific in June (Figs. 6c,f) via westward-propagating Rossby waves in the lower troposphere, which would take approximately 1 month 
(a) $300 \mathrm{hPa}$

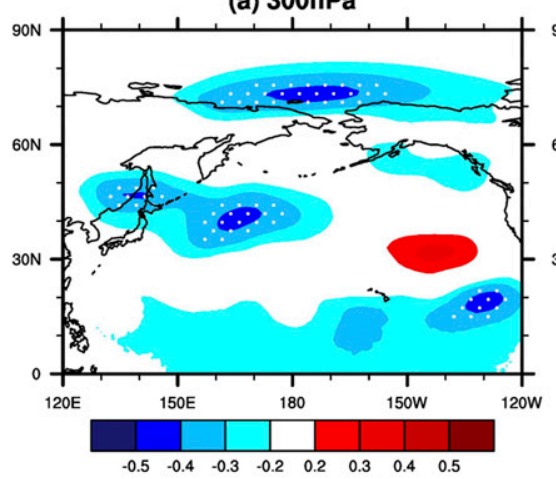

(d) $300 \mathrm{hPa}$

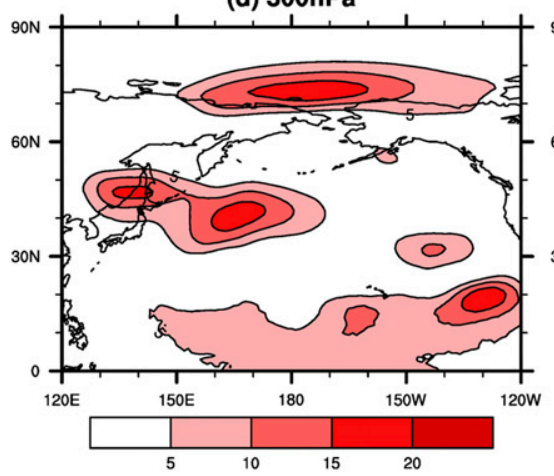

(b) $850 \mathrm{hPa}$

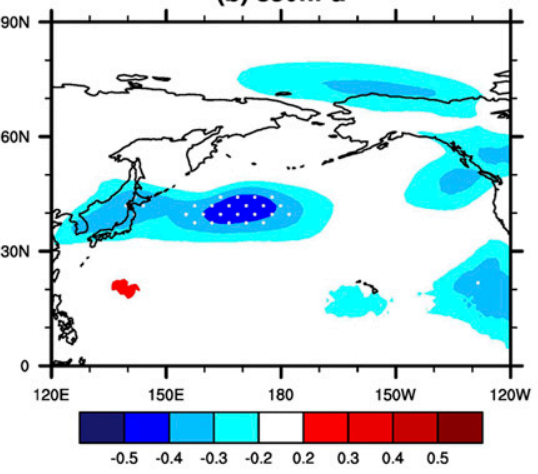

(e) $850 \mathrm{hPa}$ (c) SST

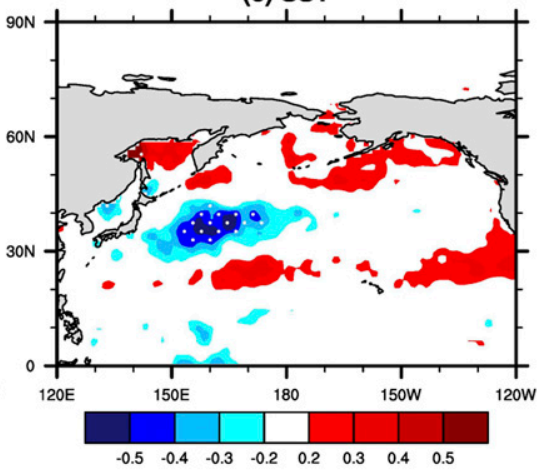

(f) SST
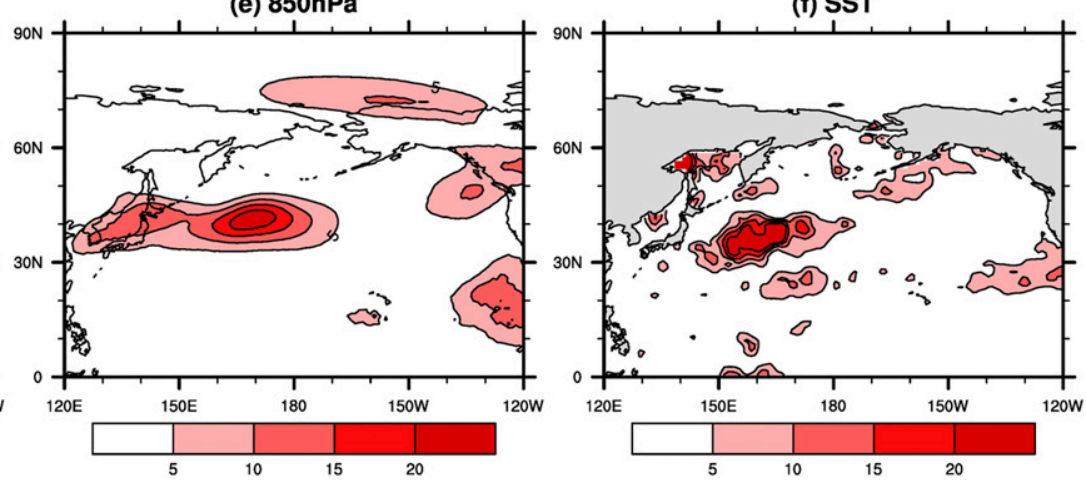

FIG. 13. Correlation coefficients between Arctic - TCO(resi) in March and (a) geopotential height at $300 \mathrm{hPa}$, (b) geopotential height at $850 \mathrm{hPa}$, and (c) SST in June. Stippled regions are statistically significant at the $95 \%$ confidence level. (d)-(f) The explained variance (\%) for (a)-(c), respectively.

(Figs. 7 and 8). Furthermore, the anomalous northerly wind over western North Pacific $\left(30^{\circ}-40^{\circ} \mathrm{N}, 140^{\circ} \mathrm{E}-180^{\circ}\right.$; Figs. 3b,d or Fig. 6c) associated with the anomalous cyclone enhances the local negative SSTAs (Figs. 2d,j or Fig. 6c). The effects of an increase in the Arctic TCO in March on the tropospheric circulation and SSTs over the western North Pacific are almost opposite to those of a decrease in March Arctic TCO.

The simulated results also indicate that the stratospheric ozone decrease contributes to NPO and VM anomalies over the North Pacific in April (Figs. 10a,d and $11 \mathrm{a}, \mathrm{d})$, which are helpful additions to previous results (Xie et al. 2016, 2017a). Moreover, the ozoneinduced anomalous cyclones over the eastern North Pacific $\left(20^{\circ}-40^{\circ} \mathrm{N}, 180^{\circ}-140^{\circ} \mathrm{W}\right)$ in May (Fig. 11e) and over the western North Pacific $\left(30^{\circ}-50^{\circ} \mathrm{N}, 120^{\circ}-140^{\circ} \mathrm{E}\right)$ in June (Fig. 11f) further support the results in the reanalysis data that the positive VM anomaly associated with the stratospheric ozone decrease develops an anomalous cyclone over the eastern North Pacific in May (Figs. 6b,e) via atmosphere-ocean coupling, which further induces an anomalous cyclone over the western North Pacific in June (Figs. 6c,f) by westwardpropagating Rossby waves (Fig. 7).
Our analysis indicates that $10 \%-20 \%$ of the variations in the tropospheric circulation and SSTs over the western North Pacific in June are affected by the Arctic TCO variations in March (Fig. 13), implying that the TCO variation in March could be a useful seasonal time scale predictor of the tropospheric circulation and SST changes over the western North Pacific in early summer. The above results also imply that the SSTs over the western North Pacific in early summer may become warmer in the future due to stratospheric ozone recovery.

Due to the large internal variability of Arctic climate, it is necessary to use a large enough ozone anomaly to distinguish robust atmospheric circulation change associated with stratospheric ozone changes from that driven by natural variability. In addition, the relationships between March Arctic TCO and the tropospheric circulation and SSTs in June are really strong in various observations and reanalysis datasets (Figs. 2-4). However, whether climate model runs underestimate the response remains unclear, which needs further study.

Acknowledgments. This work is supported by the Strategic Priority Research Program of Chinese Academy of Sciences (XDA17010106) and the National Natural 
Science Foundation of China (41630421, 41705022, and 41575038). We thank the Institute Pierre Simon Laplace (IPSL) for access to the ERA-Interim data. We thank the scientific teams at NCEP and NCAR for providing the reanalysis data.

\section{REFERENCES}

Baldwin, M. P., and T. J. Dunkerton, 2001: Stratospheric harbingers of anomalous weather regimes. Science, 294, 581-584, https://doi.org/10.1126/science.1063315.

Bitz, C. M., and L. M. Polvani, 2012: Antarctic climate response to stratospheric ozone depletion in a fine resolution ocean climate model. Geophys. Res. Lett., 39, L20705, https://doi.org/ 10.1029/2012GL053393.

Bond, N. A., J. E. Overland, M. Spillane, and P. Stabeno, 2003: Recent shifts in the state of the North Pacific. Geophys. Res. Lett., 30, 2183, https://doi.org/10.1029/2003GL018597.

Cagnazzo, C., and E. Manzini, 2009: Impact of the stratosphere on the winter tropospheric teleconnections between ENSO and the North Atlantic and European region. J. Climate, 22, 1223-1238, https://doi.org/10.1175/2008JCLI2549.1.

Calvo, N., L. M. Polvani, and S. Solomon, 2015: On the surface impact of Arctic stratospheric ozone extremes. Environ. Res. Lett., 10, 094003, https://doi.org/10.1088/1748-9326/10/9/094003.

Chen, G., and I. M. Held, 2007: Phase speed spectra and the recent poleward shift of Southern Hemisphere surface westerlies. Geophys. Res. Lett., 34, L21805, https://doi.org/ 10.1029/2007GL031200.

Chenillat, F., P. Rivière, X. Capet, E. Di Lorenzo, and B. Blanke, 2012: North Pacific Gyre Oscillation modulates seasonal timing and ecosystem functioning in the California Current upwelling system. Geophys. Res. Lett., 39, L01606, https:// doi.org/10.1029/2011GL049966.

Cheung, J. C. H., J. D. Haigh, and D. R. Jackson, 2014: Impact of EOS MLS ozone data on medium-extended range ensemble weather forecasts. J. Geophys. Res. Atmos., 119, 9253-9266, https://doi.org/10.1002/2014JD021823.

Coy, L., E. Nash, and P. Newman, 1997: Meteorology of the polar vortex: Spring 1997. Geophys. Res. Lett., 24, 2693-2696, https://doi.org/10.1029/97GL52832.

Crook, J. A., N. P. Gillett, and S. P. E. Keeley, 2008: Sensitivity of Southern Hemisphere climate to zonal asymmetry in ozone. Geophys. Res. Lett., 35, L07806, https://doi.org/ 10.1029/2007GL032698.

Ding, R., J. Li, Y.-H. Tseng, and C. Ruan, 2015a: Influence of the North Pacific Victoria mode on the Pacific ITCZ summer precipitation. J. Geophys. Res. Atmos., 120, 964-979, https:// doi.org/10.1002/2014JD022364.

,,,--- C. Sun, and Y. Guo, 2015b: The Victoria mode in the North Pacific linking extratropical sea level pressure variations to ENSO. J. Geophys. Res. Atmos., 120, 27-45, https:// doi.org/10.1002/2014JD022221.

L. Li, C. Sun, and F. Xie, 2018: Influences of the North Pacific Victoria mode on the South China Sea summer monsoon. Atmosphere, 9, 229, https://doi.org/10.3390/atmos9060229.

England, M., L. Polvani, K. Smith, L. Landrum, and M. Holland, 2016: Robust response of the Amundsen Sea low to stratospheric ozone depletion. Geophys. Res. Lett., 43, 8207-8213, https://doi.org/10.1002/2016GL070055.

Farman, J. C., B. G. Gardiner, and J. D. Shanklin, 1985: Large losses of total ozone in Antarctica reveal seasonal $\mathrm{ClO}_{x} / \mathrm{NO}_{x}$ interaction. Nature, 315, 207-210, https://doi.org/10.1038/ $315207 \mathrm{a} 0$.

Feldstein, S. B., 2011: Subtropical rainfall and the Antarctic ozone hole. Science, 332, 925-926, https://doi.org/10.1126/science.1206834.

Garfinkel, C. I., 2017: Might stratospheric variability lead to improved predictability of ENSO events? Environ. Res. Lett., 12, 031001, https://doi.org/10.1088/1748-9326/aa60a4.

— biennial oscillation on the troposphere in winter in a hierarchy of models. Part II: Perpetual winter WACCM runs. J. Atmos. Sci., 68, 2026-2041, https://doi.org/10.1175/2011JAS3702.1.

—, D. W. Waugh, and E. P. Gerber, 2013: The effect of tropospheric jet latitude on coupling between the stratospheric polar vortex and the troposphere. J. Climate, 26, 2077-2095, https://doi.org/10.1175/JCLI-D-12-00301.1.

— , M. M. Hurwitz, and L. D. Oman, 2015: Effect of recent sea surface temperature trends on the Arctic stratospheric vortex. J. Geophys. Res. Atmos., 120, 5404-5416, https://doi.org/10.1002/2015JD023284.

Gerber, E. P., and S. W. Son, 2014: Quantifying the summertime response of the austral jet stream and Hadley cell to stratospheric ozone and greenhouse gases. J. Climate, 27, 5538-5559, https://doi.org/10.1175/JCLI-D-13-00539.1.

Graf, H. F., and K. Walter, 2005: Polar vortex controls coupling of North Atlantic Ocean and atmosphere. Geophys. Res. Lett., 32, L01704, https://doi.org/10.1029/2004GL020664.

Haynes, P. H., C. J. Marks, M. E. McIntyre, T. G. Shepherd, and K. P. Shine, 1991: On the "downward control" of extratropical diabatic circulations by eddy-induced mean zonal forces. J. Atmos. Sci., 48, 651-678, https://doi.org/10.1175/ 1520-0469(1991)048<0651:OTCOED > 2.0.CO;2.

He, Y., Z. Sheng, and M. He, 2020: Spectral analysis of gravity waves from near space high-resolution balloon data in Northwest China. Atmosphere, 11, 133, https://doi.org/10.3390/atmos11020133.

Hu, D., and Z. Guan, 2018: Decadal relationship between the stratospheric Arctic vortex and Pacific decadal oscillation. J. Climate, 31, 3371-3386, https://doi.org/10.1175/JCLI-D-17-0266.1.

- W. Tian, F. Xie, C. Wang, and J. Zhang, 2015: Impacts of stratospheric ozone depletion and recovery on wave propagation in the boreal winter stratosphere. J. Geophys. Res. Atmos., 120, 8299-8317, https://doi.org/10.1002/2014JD022855.

- Z. Guan, W. Tian, and R. Ren, 2018: Recent strengthening of the stratospheric Arctic vortex response to warming in the central North Pacific. Nat. Commun., 9, 1697, https://doi.org/ 10.1038/s41467-018-04138-3.

$\mathrm{Hu}, \mathrm{Y}$., and K.-K. Tung, 2002: Interannual and decadal variations of planetary wave activity, stratospheric cooling, and Northern Hemisphere annular mode. J. Climate, 15, 1659-1673, https:// doi.org/10.1175/1520-0442(2002)015<1659:IADVOP >2.0.CO;2.

_- and _- 2003: Possible ozone-induced long-term changes in planetary wave activity in late winter. J. Climate, 16, 3027-3038, https://doi.org/10.1175/1520-0442(2003)016<3027: POLCIP $>2.0 . C O ; 2$.

, Y. Xia, and Q. Fu, 2011: Tropospheric temperature response to stratospheric ozone recovery in the 21st century. Atmos. Chem. Phys., 11, 7687-7699, https://doi.org/10.5194/acp-11-7687-2011.

Huang, J., W. Tian, J. Zhang, Q. Huang, H. Tian, and J. Luo, 2017: The connection between extreme stratospheric polar vortex events and tropospheric blockings. Quart. J. Roy. Meteor. Soc., 143, 1148-1164, https://doi.org/10.1002/qj.3001.

Hurwitz, M. M., P. A. Newman, and C. I. Garfinkel, 2012: On the influence of North Pacific sea surface temperature on the Arctic winter climate. J. Geophys. Res., 117, D19110, https:// doi.org/10.1029/2012JD017819. 
Ineson, S., and A. A. Scaife, 2009: The role of the stratosphere in the European climate response to El Niño. Nat. Geosci., 2, 32-36, https://doi.org/10.1038/ngeo381.

Ivy, D. J., S. Solomon, N. Calvo, and D. W. Thompson, 2017: Observed connections of Arctic stratospheric ozone extremes to Northern Hemisphere surface climate. Environ. Res. Lett., 12, 024004, https://doi.org/10.1088/1748-9326/aa57a4.

Jadin, E. A., K. Wei, Y. A. Zyulyaeva, W. Chen, and L. Wang, 2010: Stratospheric wave activity and the Pacific decadal oscillation. J. Atmos. Sol.-Terr. Phys., 72, 1163-1170, https:// doi.org/10.1016/j.jastp.2010.07.009.

Kang, S. M., L. M. Polvani, J. C. Fyfe, and M. Sigmond, 2011: Impact of polar ozone depletion on subtropical precipitation. Science, 332, 951-954, https://doi.org/10.1126/science.1202131.

Karoly, D. J., 1983: Rossby-wave propagation in a barotropic atmosphere. Dyn. Atmos. Oceans, 7, 111-125, https://doi.org/ 10.1016/0377-0265(83)90013-1.

Karpechko, A. Y., J. Perlwitz, and E. A. Manzini, 2014: A model study of tropospheric impacts of the Arctic ozone depletion 2011. J. Geophys. Res. Atmos., 119, 7999-8014, https://doi.org/ 10.1002/2013JD021350.

Kidston, J., A. A. Scaife, S. C. Hardiman, D. M. Mitchell, N. Butchart, M. P. Baldwin, and L. J. Gray, 2015: Stratospheric influence on tropospheric jet streams, storm tracks and surface weather. Nat. Geosci., 8, 433-440, https://doi.org/10.1038/ngeo2424.

Kren, A. C., D. R. Marsh, A. K. Smith, and P. Pilewskie, 2016: Wintertime Northern Hemisphere response in the stratosphere to the Pacific decadal oscillation using the Whole Atmosphere Community Climate Model. J. Climate, 29, 1031-1049, https://doi.org/10.1175/JCLI-D-15-0176.1.

Kumar, K. K., B. Rajagopalan, and M. A. Cane, 1999: On the weakening relationship between the Indian monsoon and ENSO. Science, 284, 2156-2159, https://doi.org/10.1126/ science.284.5423.2156.

Labitzke, K., and B. Naujokat, 2000: The lower Arctic stratosphere in winter since 1952. SPARC Newsletter, No. 15, SPARC Office, Toronto, ON, Canada, 11-14, http://www.atmosp. physics.utoronto.ca/SPARC/News15/15_Labitzke.html.

Lefèvre, F., F. Figarol, K. S. Carslaw, and T. Peter, 1998: The 1997 Arctic ozone depletion quantified from three-dimensional model simulations. Geophys. Res. Lett., 25, 2425-2428, https://doi.org/10.1029/98GL51812.

Lenaerts, J. T. M., J. Fyke, and B. Medley, 2018: The signature of ozone depletion in recent Antarctic precipitation change: A study with the Community Earth System Model. Geophys. Res. Lett., 45, 12 931-12 939, https://doi.org/10.1029/2018GL078608.

Li, F., Y. V. Vikhliaev, P. A. Newman, S. Pawson, J. Perlwitz, D. W. Waugh, and A. R. Douglass, 2016: Impacts of interactive stratospheric chemistry on Antarctic and Southern Ocean climate change in the Goddard Earth Observing System, version 5 (GEOS-5). J. Climate, 29, 3199-3218, https://doi.org/ 10.1175/JCLI-D-15-0572.1.

Li, Y., J. Li, F. Jin, and S. Zhao, 2015: Interhemispheric propagation of stationary Rossby waves in the horizontally nonuniform background flow. J. Atmos. Sci., 72, 3233-3256, https:// doi.org/10.1175/JAS-D-14-0239.1.

Ma, X., F. Xie, J. Li, X. Zheng, W. Tian, R. Ding, C. Sun, and J. Zhang, 2019: Effects of Arctic stratospheric ozone changes on spring precipitation in the northwestern United States. Atmos. Chem. Phys., 19, 861-875, https://doi.org/10.5194/acp-19-861-2019.

Manney, G., and Coauthors, 2011: Unprecedented Arctic ozone loss in 2011. Nature, 478, 469-475, https://doi.org/10.1038/ nature10556.
Mantua, N. J., S. R. Hare, Y. Zhang, J. M. Wallace, and R. C. Francis, 1997: A Pacific interdecadal climate oscillation with impacts on salmon production. Bull. Amer. Meteor. Soc., 78 , 1069-1079, https://doi.org/10.1175/1520-0477(1997)078<1069: APICOW $>2.0 . C O ; 2$.

Marsh, D. R., M. J. Mills, D. E. Kinnison, J.-F. Lamarque, N. Calvo, and L. M. Polvani, 2013: Climate change from 1850 to 2005 simulated in CESM1(WACCM). J. Climate, 26, 73727391, https://doi.org/10.1175/JCLI-D-12-00558.1.

Marshall, G. J., A. Orr, N. P. M. van Lipzig, and J. C. King, 2006: The impact of a changing Southern Hemisphere annular mode on Antarctic Peninsula summer temperatures. J. Climate, 19, 5388-5404, https://doi.org/10.1175/JCLI3844.1.

Min, S.-K., and S.-W. Son, 2013: Multimodel attribution of the Southern Hemisphere Hadley cell widening: Major role of ozone depletion. J. Geophys. Res. Atmos., 118, 3007-3015, https://doi.org/10.1002/JGRD.50232.

Pawson, S., and B. Naukokat, 1999: The cold winters of the middle 1990s in the northern lower stratosphere. J. Geophys. Res., 104, 14 209-14 222, https://doi.org/10.1029/1999JD900211.

Polvani, L. M., D. W. Waugh, G. J. P. Correa, and S.-W. Son, 2011: Stratospheric ozone depletion: The main driver of twentiethcentury atmospheric circulation changes in the Southern Hemisphere. J. Climate, 24, 795-812, https://doi.org/10.1175/ 2010JCLI3772.1.

$\mathrm{Pu}$, X., Q. Chen, Q. Zhong, R. Ding, and T. Liu, 2019: Influence of the North Pacific Victoria mode on western North Pacific tropical cyclone genesis. Climate Dyn., 52, 245-256, https:// doi.org/10.1007/s00382-018-4129-z.

Ramaswamy, V., M. D. Schwarzkopf, and W. J. Randel, 1996: Fingerprint of ozone depletion in the spatial and temporal pattern of recent lower stratospheric cooling. Nature, 382, 616-618, https://doi.org/10.1038/382616a0.

Randel, W. J., and F. Wu, 1999: Cooling of the Arctic and Antarctic polar stratospheres due to ozone depletion. J. Climate, 12, 1467-1479, https://doi.org/10.1175/1520-0442(1999)012<1467: COTAAA $>2.0 . \mathrm{CO} ; 2$.

— , and — 2007: A stratospheric ozone profile data set for 1979-2005: Variability, trends, and comparisons with column ozone data. J. Geophys. Res., 112, D06313, https://doi.org/ 10.1029/2006JD007339.

Ravishankara, A. R., A. A. Turnipseed, N. R. Jensen, S. Barone, M. Mills, C. J. Howard, and S. Solomon, 1994: Do hydrofluorocarbons destroy stratospheric ozone? Science, 263, 7175, https://doi.org/10.1126/science.263.5143.71.

_ J. S. Daniel, and R. W. Portmann, 2009: Nitrous oxide $\left(\mathrm{N}_{2} \mathrm{O}\right)$ : The dominant ozone-depleting substance emitted in the 21 st century. Science, 326, 123-125, https://doi.org/10.1126/science.1176985.

Reichler, T., J. Kim, E. Manzini, and J. Kröger, 2012: A stratospheric connection to Atlantic climate variability. Nat. Geosci., 5, 783-787, https://doi.org/10.1038/ngeo1586.

Russell, J. L., K. W. Dixon, A. Gnanadesikan, R. J. Stouffer, and J. R. Toggweiler, 2006: The Southern Hemisphere westerlies in a warming world: Propping open the door to the deep ocean. J. Climate, 19, 6382-6390, https://doi.org/10.1175/JCLI3984.1.

Scaife, A. A., J. R. Knight, G. K. Vallis, and C. K. Folland, 2005: A stratospheric influence on the winter NAO and North Atlantic surface climate. Geophys. Res. Lett., 32, L18715, https:// doi.org/10.1029/2005GL023226.

Schoeberl, M. R., and D. L. Hartmann, 1991: The dynamics of the stratospheric polar vortex and its relation to springtime ozone depletions. Science, 251, 46-52, https://doi.org/10.1126/ science.251.4989.46. 
Seviour, W. J. M., A. Gnanadesikan, and D. W. Waugh, 2016: The transient response of the Southern Ocean to stratospheric ozone depletion. J. Climate, 29, 7383-7396, https://doi.org/ 10.1175/JCLI-D-16-0198.1.

Sheng, Z., Y. Jiang, L. Wan, and Z. Fan, 2015: A study of atmospheric temperature and wind profiles obtained from rocketsondes in the Chinese midlatitude region. J. Atmos. Oceanic Technol., 32, 722735, https://doi.org/10.1175/JTECH-D-14-00163.1.

Smith, K. L., and L. M. Polvani, 2014: The surface impacts of Arctic stratospheric ozone anomalies. Environ. Res. Lett., 9, 074015 , https://doi.org/10.1088/1748-9326/9/7/074015.

Solomon, S., 1990: Progress towards a quantitative understanding of Antarctic ozone depletion. Nature, 347, 347-354, https:// doi.org/10.1038/347347a0.

_ 1999: Stratospheric ozone depletion: A review of concepts and history. Rev. Geophys., 37, 275-316, https://doi.org/ 10.1029/1999RG900008.

_ ences between Arctic and Antarctic ozone depletion. Proc Natl. Acad. Sci. USA, 111, 6220-6225, https://doi.org/10.1073/ pnas.1319307111.

Son, S. W., and Coauthors, 2008: The impact of stratospheric ozone recovery on the Southern Hemisphere westerly jet. Science, 320, 1486-1489, https://doi.org/10.1126/science.1155939.

—, N. F. Tandon, L. M. Polvani, and D. W. Waugh, 2009: Ozone hole and Southern Hemisphere climate change. Geophys. Res. Lett., 36, L15705, https://doi.org/10.1029/2009GL038671.

_ - and Coauthors, 2010: Impact of stratospheric ozone on Southern Hemisphere circulation change: A multimodel assessment. J. Geophys. Res., 115, D00M07, https://doi.org/ 10.1029/2010JD014271.

Song, L., Y. Li, and W. Duan, 2016: The influence of boreal winter extratropical North Pacific Oscillation on Australian spring rainfall. Climate Dyn., 47, 1181-1196, https://doi.org/10.1007/ s00382-015-2895-4.

Song, Y., and W. A. Robinson, 2004: Dynamical mechanisms for stratospheric influences on the troposphere. J. Atmos. Sci., 61 , 1711-1725, https://doi.org/10.1175/1520-0469(2004)061<1711: DMFSIO $>2.0 . \mathrm{CO} ; 2$.

Stolarski, R. S., and S. M. Frith, 2006: Search for evidence of trend slow-down in the long-term TOMS/SBUV total ozone data record: The importance of instrument drift uncertainty. Atmos. Chem. Phys., 6, 4057-4065, https://doi.org/10.5194/ acp-6-4057-2006.

Thompson, D. W. J., S. Solomon, P. J. Kushner, M. H. England, K. M. Grise, and D. J. Karoly, 2011: Signatures of the Antarctic ozone hole in Southern Hemisphere surface climate change. Nat. Geosci., 4, 741-749, https://doi.org/10.1038/ngeo1296.

Tian, W., M. P. Chipperfield, D. S. Stevenson, R. Damoah, S. Dhomse, A. Dudhia, H. Pumphrey, and P. Bernath, 2010: Effects of stratosphere-troposphere chemistry coupling on tropospheric ozone. J. Geophys. Res., 115, D00M04, https:// doi.org/10.1029/2009JD013515.

Turner, J., and Coauthors, 2005: Antarctic climate change during the last 50 years. Int. J. Climatol., 25, 279-294, https://doi.org/ 10.1002/joc. 1130

van der A, R. J., M. A. F. Allaart, and H. J. Eskes, 2010: Multi sensor reanalysis of total ozone. Atmos. Chem. Phys., 10, 11277-11 294, https://doi.org/10.5194/acp-10-11277-2010.

,$- \ldots$, and -2015 : Extended and refined multi sensor reanalysis of total ozone for the period 1970-2012. Atmos. Meas. Tech., 8, 3021-3035, https://doi.org/10.5194/amt-8-3021-2015.
Vimont, D. J., D. S. Battisti, and A. C. Hirst, 2003: The seasonal footprinting mechanism in the CSIRO general circulation models. J. Climate, 16, 2653-2667, https://doi.org/10.1175/ 1520-0442(2003)016<2653:TSFMIT >2.0.CO;2.

Wang, B., R. Wu, and X. Fu, 2000: Pacific-East Asian teleconnection: How does ENSO affect East Asian climate? J. Climate, 13, 1517-1536, https://doi.org/10.1175/1520-0442(2000)013<1517: PEATHD $>2.0 . \mathrm{CO} ; 2$

Waugh, D. W., L. Oman, P. A. Newman, R. S. Stolarski, S. Pawson, J. E. Nielsen, and J. Perlwitz, 2009: Effect of zonal asymmetries in stratospheric ozone on simulated Southern Hemisphere climate trends. Geophys. Res. Lett., 36, L18701, https://doi.org/10.1029/2009GL040419.

, C. I. Garfinkel, and L. M. Polvani, 2015: Drivers of recent tropical expansion in the Southern Hemisphere: Changing SSTs or ozone depletion? J. Climate, 28, 6581-6586, https:// doi.org/10.1175/JCLI-D-15-0138.1.

- A. H. Sobel, and L. M. Polvani, 2017: What is the polar vortex and how does it influence weather? Bull. Amer. Meteor. Soc., 98, 37-44, https://doi.org/10.1175/BAMS-D-15-00212.1.

WMO, 2011: Scientific assessment of ozone depletion: 2010 Technical Report. Global Ozone Research and Monitoring Project Rep. 52, 516 pp.

Woo, S.-H., M.-K. Sung, S.-W. Son, and J.-S. Kug, 2015: Connection between weak stratospheric vortex events and the Pacific decadal oscillation. Climate Dyn., 45, 3481-3492, https://doi.org/10.1007/s00382-015-2551-z.

Xia, Y., Y. Hu, and Y. Huang, 2016: Strong modification of stratospheric ozone forcing by cloud and sea-ice adjustments. Atmos. Chem. Phys., 16, 7559-7567, https://doi.org/10.5194/ acp-16-7559-2016.

Xie, F., and Coauthors, 2016: A connection from Arctic stratospheric ozone to El Niño-Southern Oscillation. Environ. Res. Lett., 11, 124026, https://doi.org/10.1088/1748-9326/11/12/124026.

— , and Coauthors, 2017a: Variations in North Pacific sea surface temperature caused by Arctic stratospheric ozone anomalies. Environ. Res. Lett., 12, 114023, https://doi.org/10.1088/17489326/aa9005.

- and Coauthors, 2017b: Delayed effect of Arctic stratospheric ozone on tropical rainfall. Atmos. Sci. Lett., 18, 409-416, https://doi.org/10.1002/asl.783.

— spheric ozone changes on spring precipitation in China. Climate Dyn., 51, 4029-4041, https://doi.org/10.1007/s00382018-4402-1.

Xie, S.-P., and S. G. H. Philander, 1994: A coupled ocean-atmosphere model of relevance to the ITCZ in the eastern Pacific. Tellus, 46A, 340-350, https://doi.org/10.3402/tellusa.v46i4.15484.

Zhang, J., W. Tian, Z. Wang, F. Xie, and F. Wang, 2015: The influence of ENSO on northern midlatitude ozone during the winter to spring transition. J. Climate, 28, 4774-4793, https:// doi.org/10.1175/JCLI-D-14-00615.1.

— — - M. P. Chipperfield, F. Xie, and J. Huang, 2016: Persistent shift of the Arctic polar vortex towards the Eurasian continent in recent decades. Nat. Climate Change, 6, 1094 1099, https://doi.org/10.1038/nclimate3136. and Coauthors, 2018: Stratospheric ozone loss over the Eurasian continent induced by the polar vortex shift. Nat. Commun., 9, 206, https://doi.org/10.1038/s41467-017-02565-2.

Zhang, Y., J. M. Wallace, and D. S. Battisti, 1997: ENSO-like interdecadal variability: 1900-93. J. Climate, 10, 1004-1020, https:// doi.org/10.1175/1520-0442(1997)010<1004:ELIV>2.0.CO;2. 